Research Article/Araştırma Makalesi

\title{
Evaluation of Free Event Applications According to Class Teachers' Views
}

\author{
Mehtap SARAÇOĞLU * 1 (D) Yunus Emre ÇİFTÇİ 2 (iD \\ ${ }^{1}$ Siirt University, Faculty of Education, Siirt, Turkey, mehtapsarac@siirt.edu.tr \\ ${ }^{2}$ Ministry of Education, Diyarbakır, Turkey, emre1988.ye@gmail.com \\ * Corresponding Author: mehtapsarac@siirt.edu.tr
}

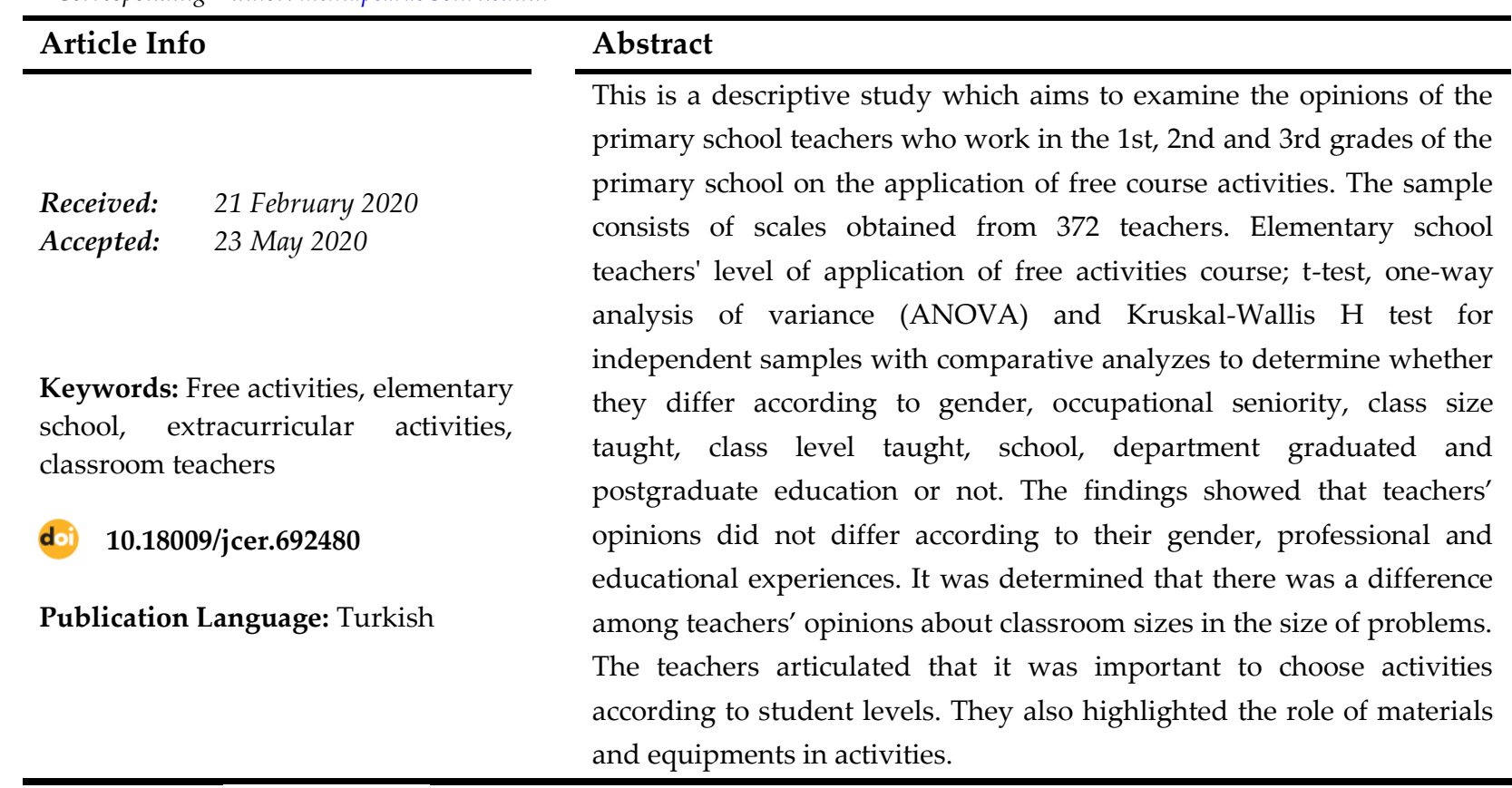

open $\bigcirc$ access $(a)$ CrossMark (C)

To cite this article: Saraçoğlu, M. \& Çiftçi, Y.E. (2020). Serbest etkinlik uygulamalarının sınıf öğretmenlerinin görüşlerine göre değerlendirilmesi. Journal of Computer and Education Research, 8 (16), 356-385. DOI: 10.18009/jcer.692480

\section{Serbest Etkinlik Uygulamalarının Sınıf Öğretmenlerinin Görüşlerine Göre Değerlendirilmesi}

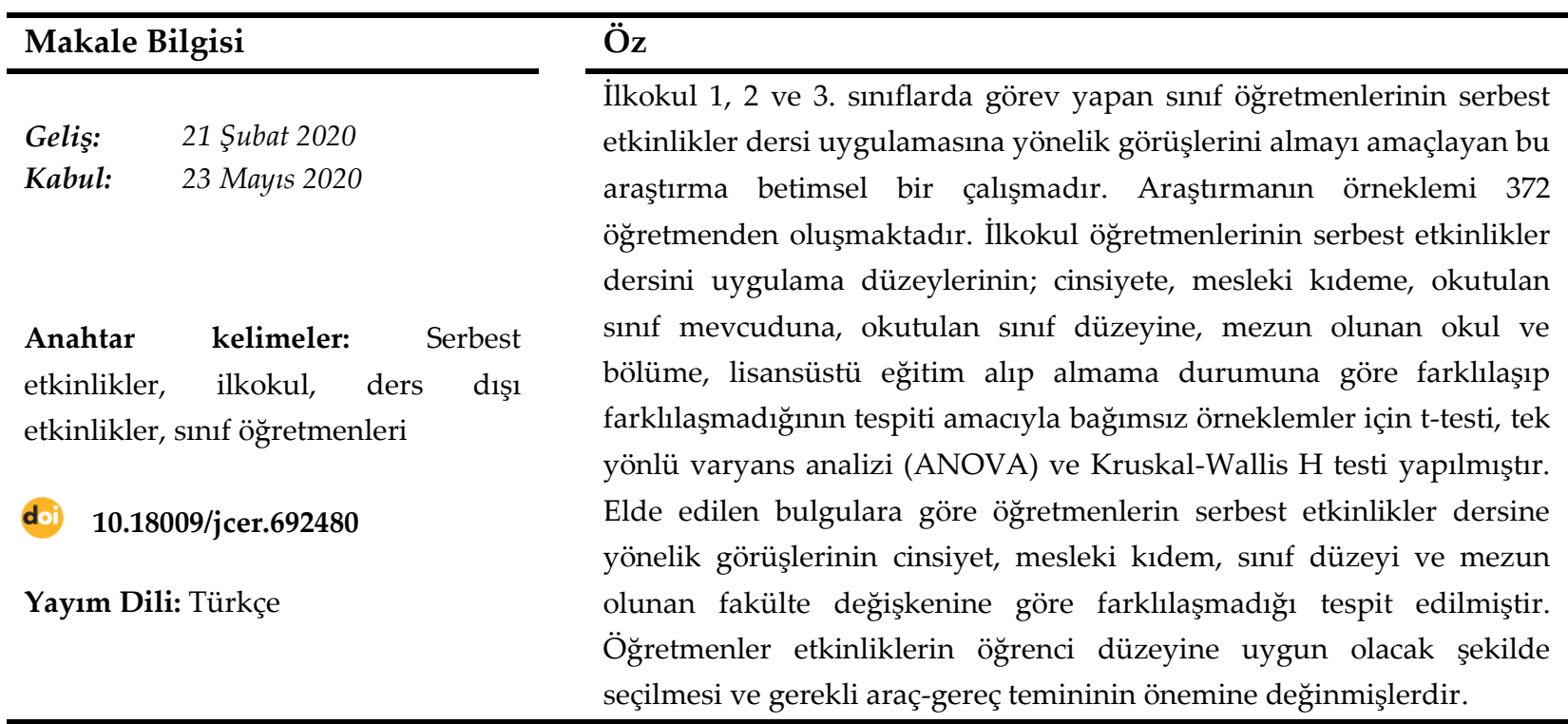




\section{Summary}

\section{Evaluation of Free Event Applications According to Class Teachers' Views}

\section{Introduction}

This study examines teachers' opinions about the implementations of free activities. The purpose of free course activities, which came into effect in 2010 and 2011 academic year, is to reduce compulsory courses, improve students' life skills by participating in different social, cultural and art activities and to develop moral characters (Kazu \& Arslan, 2013). This means that these activities are important and necessary for students learning and development.

\section{Method}

The research method is a survey model that is used to collect teachers' opinions about free activities in $1^{\text {st }}, 2^{\text {nd }}$ and $3^{\text {rd }}$ grades of primary schools. The participants of the study are 2804 primary school teachers working in 206 different schools in the districts of Kayapinar, Baglar and Sur of Diyarbakir City in 2017 and 2018 academic year. Questionaries were obtained from 372 teachers. As a data collection tool, "The Questionnaire for the Evaluation of Free Activity Courses Applying in Elementary Schools Based on Teachers' Opinions" developed by Özsel (2016) was used to examine teachers' opinions about free course activities. In this study, demographic and frequency items, which are related to the scale, arithmetic average and standard deviation, were provided after the normal distribution of data had been determined. For independent samples, the implementation of HIA of primary school teachers was determined with comparison analysis; the t-test, one-way analysis of variance (ANOVA) and Kruskal-Wallis $\mathrm{H}$ test. The purpose of detection was to find whether the t-test and one-way analysis differed according to gender, professional experience, teaching experience and post-graduate education or not. 


\section{Results}

The results show that teachers structure different activities. Findings relating to the other courses supplement have been identified as "sometimes", that is, at a medium level. The teachers sometimes used the reinforcement of other lessons in the free activities lesson. Based on the findings, the study concluded that activities which the teachers spared at least one-hour time were folk dances and vegetable-fruit growing activities. It was found that the challenges identified were a lack of materials such as textbooks and equipments, crowded classrooms and inadequate classroom sizes. The study suggests that teachers highlight the importance of students' level for choosing activities and of necessary tools and equipment for those activities.

\section{Discussion and Conclusion}

Based on the findings, it was determined that teachers' opinions about the free course activities did not differ in terms of gender variable. It was determined that teachers' opinions about free activities lesson differed in terms of class sizes. It was found that teachers who have 35 or more students in their classes experienced more problems in the free activities than other activities. It was observed that teachers whose classroom sizes varied from 5-14 had higher participation in planning, implementation, activities and suggestions. For the free lesson activities, we can say that the teachers have problems as it is difficult to perform activities in crowded classrooms and to control the class. The analysis of teachers' opinions about free activities did not show a significant difference in terms of the classroom level variable, as well as the relationships between activity time and graduated variables. But it was observed that there was a significant difference between planning and implementation, and having master degrees as teachers who had a master degree participated more in planning and implementation than those who did not have. Thus it can be said that the teachers who had a master's degree paid more attention to the planning and implementation of the free activities. According to the findings, the current research suggests that a master's degree has an impact on and contribution to teachers' professional development. 


\section{Giriş}

Eğitim alanında yapılan çalışmalar ve yenilikler arttıkça yetişen öğrenci profili de daha nitelikli ve donanımlı olmaktadır. Eğitimdeki yenilik ve değişimler aynı zamanda toplumu da etkilemektedir. Dünya düzeni içerisinde sürekli değişim süreçleri vardır. Bu değişimler hem toplumu hem de bireyleri etkilemektedir (Ika-Mayasari, Akbar \& Sari, 2020; Tozlu, 2014). Toplumun refaha kavuşmasında eğitimin önemli bir rolü vardır. Eğitim toplumun gelişmesi ve ilerlemesinde en önemli etmenlerdendir.

Ülkeler eğitim ile ilgili yaptıkları çalışmalarda eğitimde gerçekleşen değişimleri dikkate almalıdırlar. Böylece kendi eğitim felsefelerini, politikalarını şekillendirerek bireylerin gelişimine katkı sağlayabilirler. Değişim ve gelişim içerisinde olan eğitim, içerik ve amaçlar noktasında değişime uğramıştır. Öğrencinin istek ve ihtiyaçlarına cevap veremez hale gelen geleneksel eğitimden vazgeçilmiştir. Öğrencinin bilgiyi ezberleyerek veya olduğu gibi alması düşüncesi geçerliliğini yitirmiş durumdadır (İlhan-Beyaztaş, Kaptı \& Senemoğlu, 2013). Okulda öğrenilenlerin gerçek yaşam deneyimleri ile birlikte anlamlı kılındığı ve gerçek hayata aktarılabildiği noktada anlamlı olacağı görüşü hâkim olmuştur. Öğrenci gerçek yaşam deneyimleri ile bilgiyi elde etmeli ve elde ettiği bilgiyi kullanabilmelidir (Tüfekçi-Aslım, 2014). Bu sebeplerden dolayı 2005-2006 eğitim-öğretim programında benimsenmiş olan yapılandırmacı eğitim anlayışı, bireyin öğretimin merkezinde olduğu ve kendi öğrenmesinden sorumlu olduğu şekilde ilerleyen bir sistemdir (İlhan-Beyaztaş vd., 2013; Özsel, 2016). Öğretmen sinıfta tartışma ortamı sağlayarak, öğrencilerin kendi ön bilgilerini kullanarak, yeni bilgiyi yapılandırmalarına rehberlik eder (Baysen \& Silman, 2012; Kutluca, 2013). Öğrencilerin bilgiyi kendilerinin oluşturmasından hareketle yaparak yaşayarak öğrenmenin önem kazandığı yapılandırmacı yaklaşım ile ilgili John Dewey ünlü eseri olan “Demokrasi ve Eğitim" adlı kitabında bireyin yaparak yaşayarak öğrenmesini esas alarak, bireyin deneyerek ve çevreyle etkileşim içine girerek kalıcı öğrenmeler gerçekleştireceğini belirtir (Gutek, 2014).

Bloom'un tam öğrenme modeli uygun koşullar sağlandığında öğrencilerin büyük bir çoğunluğunun öğrenebileceğini savunmaktadır. Tam öğrenme modelinde, özellikle öğrenci niteliklerinin öğrenme üzerinde önemli bir etkisi vardır. Bilişsel ve duyuşsal giriş davranışları öğrencinin akademik başarısını belirleyici bir role sahiptir. Duyuşsal giriş özellikleri, öğrencinin derslere ve okula karşı ilgi ve tutumunu ifade etmektedir (Gökalp, 2014:331). Özellikle okula ve derslere karşı duyuşsal giriş davranışlarının olumlu yöne doğru 
çevrilmesini sağlayabilmek açısından okullarda yapılacak ders içi ve ders dışı sosyal ve sanatsal aktivitelerin önemi büyüktür.

Ders dışı öğrenme, öğrenciye ciddi katkılar sağlamaktadır. Ders dışı etkinlikler öğrencilerin öğrenme güdüsünü artırmakta, kişilik gelişimi, ahlaki gelişim, okul kültürüne uyum gösterme konusunda olumlu tutumlar geliştirme, liderlik özelliklerinin gelişmesi, serbest zamanlarını kaliteli bir şekilde değerlendirebilme, motivasyonu arttırma, sosyal etkileşim ve bilgi aktarımı ile ilgili bağlayıcı olma gibi birçok konuda katkılar sağlamaktadır. Söz konusu katkıların daha etkili olabilmesi için ders dışı etkinliklerin diğer derslerle ilişkilendirilmesi ve öğrencinin yaşantısı ile bütünleştirilmiş olması gerekir (Köse, 2004). Gifford ve Dean'in (1990) araştırmalarında ders dışı etkinliklere katılan öğrencilerin okula karşı olumlu tutum geliştirdikleri belirlenmiştir. Fletcher, Nickerson ve Wright (2003) araştırmalarında planlı yapılan boş zaman etkinliklerine katılan öğrencilerin katılamayan öğrencilere göre daha fazla akademik başarı ve psikolojik gelişme gösterdiklerini tespit etmişlerdir. Holloway (2000) araştırmasında ders dişı etkinliklerin öğrencilerin akademik başarıları, sorumluluk, iletişim kurma, grup çalışması gibi becerileri kazanmalarını sağlayarak olumlu okul kültürünün oluşmasını sağladığını belirtmiştir.

Ders dişı etkinliklerin amacına iyi hizmet edebilmesi için bu etkinliklerin düzenli bir şekilde hazırlanmış olması gerekir. Eğitim-öğretim faaliyetleri içerisinde ders dişı etkinlikler, öğretmen ve öğrencilerin katılımıyla planlanır, bunun kontrolü ve denetimi okul yönetimi tarafından gerçekleştirilir (Köse, 2004). Ders dışı etkinlikler planlı ve daha kapsamlı şekilde 2010 yılında Milli Eğitim Bakanlığı Talim Terbiye Kurulu Başkanlığı tarafından yapılan yeni bir düzenleme ile serbest etkinlikler dersi şeklinde ilkokulların 1-5. sınıflarının haftalık ders çizelgesinde yer almaya başlamıştır. İlköğretim Okulları Haftalık Ders Çizelgesi incelendiğinde Türkçe, Hayat Bilgisi, Fen ve Teknoloji derslerinin ders saatleri azaltılmıştır. 12 saat olan Türkçe dersi 11 saate, 5 saat olan Hayat Bilgisi dersi 4 saate, 4 saat olan Fen ve Teknoloji dersi 3 saate düşürülmüştür. Böylece serbest etkinlikler dersi için öngörülen zaman dilimi sağlanmaya çalışılmıştır. Serbest etkinlikler dersi 1,2 ve 3. sınıflarda 5 saat, 4 . ve 5 . sınıflarda 4 saat olacak şekilde düzenlenmiştir (Milli Eğitim Bakanlığ1 [MEB], 2010). 2012 yılında 12 yıllık zorunlu eğitim getirilmiş ve $4+4+4$ sistemi ile haftalık ders çizelgelerinde değişikliğe gidilmiştir (MEB, 2012). 1, 2 ve 3. sınıflarda 2016 y1lından itibaren serbest etkinlikler dersi uygulanmaya devam edilmiştir. Serbest etkinlikler dersinin ilkokul programlarında yer alması ile hem zorunlu ders yükünü azaltmak hem de öğrencilerin farklı 
sosyal, kültürel, sanatsal ve eğitsel etkinliklere katılarak yaşam becerilerini geliştirmeleri, iyi ahlaki özelliklere sahip olmaları ve olumlu karakter gelişimi sağlanması amaçlanmıştır (Kazu \& Arslan, 2013). Serbest etkinlikler dersi ile ulaşılması beklenen amaçlar ve ortaya çıkacak ürünler göz önüne alındığında çok önemli ve gerekli bir ders olduğu anlaşılmaktadır. Bu derste yapılacak olan etkinlikler öğrencilerin, eğlenerek öğrenmelerini, yaratıcılık ve hayal güçlerinin gelişmesini, işbirliği içinde çalışarak yardımlaşma, dayanışma ve özgüven gibi beceri ve değerleri kazandıracak nitelikte olmalıdır (Dündar \& Karaca, 2011).

Bu araştırmada ilkokul 1, 2 ve 3. sınıflarda görev yapan sınıf öğretmenlerinin serbest etkinlikler dersinde sınıflarında yapmış oldukları etkinliklerin neler olduğu, nasıl bir planlama yaptıkları, uygulama aşamasında yaşanan sorunlar ve öneriler hakkında bilgi sahibi olunmaya çalışılmıştır. Bu araştırmadan elde edilecek olan verilerin serbest etkinlikler dersinin uygulanması ve geliştirilmesi açısından alana katkı sağlayacağı düşünülmektedir.

\section{Araştırmanın Amacı}

$\mathrm{Bu}$ araştırmanın genel amacı, ilkokul 1, 2 ve 3. sınıflarda görev yapan sınıf öğretmenlerinin serbest etkinlikler dersi uygulanmasına yönelik görüşlerini belirlemektir. Serbest etkinlik uygulamalarının cinsiyet, kıdem, sınıf mevcudu, sınıf düzeyi, mezun olunan fakülte ve eğitim düzeyleri değişkenlerine göre farklılaşıp farklılaşmadığı araştırılmıştır. Araştırmanın temel amacına bağlı olarak geliştirilen alt problemlere aşağıda yer verilmiştir:

1. İlkokullarda uygulanan serbest etkinlikler dersine ilişkin öğretmen görüşleri nelerdir?

2. İlkokullarda uygulanan serbest etkinlikler dersine ilişkin öğretmen görüşleri; cinsiyet, mesleki kıdem, sınıf mevcudu, sınıf düzeyi, mezun olunan fakülte ve lisansüstü eğitim alma değişkenlerine göre anlamlı farklılık göstermekte midir?

\section{Yöntem}

\section{Araştırmanın Modeli}

$\mathrm{Bu}$ araştırma, serbest etkinlikler dersi ile ilgili öğretmen görüşlerini belirlemek amacıyla yapılan betimsel bir çalışmadır. Bu nedenle tarama modellerinden betimsel tarama modeli benimsenmiştir. Tarama modeli, geçmişte veya halen var olan durumu olduğu gibi belirlemeyi hedef edinmiş bir araştırmadır. Araştırmada incelemeye alınmış olan olay, durum, nesne veya birey bulunduğu koşullar içerisinde betimlenmeye çalışılır. Araştırmacı 
herhangi bir etkileme ve değiştirme gibi etkilerde bulunmaz. Olduğu gibi gözlenip belirlenmesi esastır (Karasar, 2015).

\section{Evren-Örneklem}

Araştırmanın evrenini, 2017-2018 eğitim öğretim yılında Diyarbakır ili merkez ilçelerinde (Kayapınar, Yenişehir, Bağlar, Sur) bulunan 206 ilkokulda görev yapan 2804 sınıf öğretmeni oluşturmaktadır. Diyarbakır’da basit tesadüfi örnekleme yapılarak ilkokullardan 415 ölçek geri dönütü alınmıştır. Basit tesadüfi örneklemde, evrende yer alan elemanların örnekleme girme durumları tamamıyla şansa dayalıdır (Karasar, 2015). Bu ölçekler içerisinden 43 tanesi yanlış ve eksik işaretlemelerden dolayı değerlendirmeye alınmamıştır. 372 ölçek ise geçerli kabul edilip değerlendirmeye alınmıştır. 0.05 düzeyinde 3000 evren değerine karşılık gelen örneklem değeri en az 341 olarak önerilmiştir (Büyüköztürk, KılıçÇakmak, Akgün, Karadeniz \& Demirel, 2012). Buna göre; 372 örneklem sayısının yeterli olduğu düşünülmektedir.

Tablo 1. Araştırmaya Katılan Sınıf Öğretmenlerinin Demografik Nitelikleri

\begin{tabular}{llll}
\hline Demografik Nitelik & Gruplar & N & \% \\
\hline Cinsiyet & Kadın & 165 & 44.4 \\
Mesleki Kıdem & Erkek & 207 & 55.6 \\
& 1-5 yıl arası & 47 & 12.6 \\
& 6-10 yıl arası & 74 & 19.9 \\
& 11-15 yıl arası & 82 & 22.0 \\
& 16-20 yıl arası & 76 & 20.4 \\
& 21-25 yıl arası & 64 & 17.2 \\
Sınıf Mevcudu & 26 yıl ve üzeri & 29 & 7.8 \\
& 5-14 arası öğrenci & 19 & 5.1 \\
& 15-24 arası öğrenci & 54 & 14.5 \\
Okuttuğu Sınıf Düzeyi & 25-34 arası öğrenci & 150 & 40.3 \\
& 35 ve üzeri öğrenci & 149 & 40.1 \\
& 1.sınıf & 116 & 31.2 \\
Mezun Olunan Fakülte & E.sınıf & 130 & 34.9 \\
& Diğger & 126 & 33.9 \\
Lisansüstü Eğitim Alma & 323 & 86.8 \\
Durumu & Evet & 49 & 13.2 \\
& Hayır & 31 & 8.3 \\
\hline & Toplam & 341 & 91.7 \\
\hline
\end{tabular}

Veri Toplama Araçları

Araştırmada veri toplama aracı olarak, Özsel (2016) tarafından serbest etkinlikler dersinin sınıf öğretmenlerinin görüşlerine dayalı olarak incelenmesi amacıyla geliştirilen “ilkokullarda Uygulanan Serbest Etkinlik Saatlerinin Öğretmen Görüşlerine Dayalı Olarak 
Değerlendirilmesi Ölçeği” kullanılmıştır. Ölçek, iki bölümden ve 64 sorudan oluşmaktadır. Birinci bölümde, öğretmenlerin kişisel bilgilerini (cinsiyet, mesleki kıdem, ortalama sınıf mevcudu, okutulan sınıf düzeyi, mezun olunan okul türü ve bölüm, lisansüstü eğitim durumu) toplamaya yönelik sorular yer almaktadır. İkinci bölümde ise, serbest etkinlikler dersini planlama, uygulama, etkinlikler, sorunlar ve öneriler boyutlarıla ilgili sorular yer almaktadır. Ölçekte; Cronbach alpha güvenirlik katsayısı .92 olarak belirlenmiştir. Boyutlar kısmında Cronbach Alpha güvenirlik katsayıları; dersi planlama aşamasında .91, dersin uygulanabilirliği ve etkililiği .85, derste yapılan etkinlikler .91, derste karşılaşılan sorunlar .90 ve dersle ilgili sunulan öneriler boyutunda .87 olarak hesaplanmıştır.

\section{Verilerin Analizi}

Öğretmenlerin, ilkokullarda uygulanan serbest etkinlikler dersine yönelik boyutlar temelinde genel görüşlerinin betimlenmesinde betimsel istatistiklerden yararlanılmıştır. Öğretmenlerin serbest etkinlikler dersine ilişkin görüşlerini belirlemek için uygulanan ölçekten elde edilen verilerin analizinde kullanılacak istatistiksel yöntemleri belirlemek amacıyla, normal dağılıma uygunluk analizinde Kolmogorov-Smirnov testi, verilerin homojenlik durumunu tespit etmek için de Levene testi kullanılmıştır. Bu sınamaların sonuçlarına göre; cinsiyet, mezun olunan fakülte ve lisansüstü eğitim alma durumu değişkenlerinde bağımsız örneklemler için $t$ testi, mesleki kıdem ve okuttuğu sınıf düzeyi değişkenlerinde ilişkisiz örneklemler için tek yönlü varyans analizi (ANOVA), sınıf mevcudu değişkeninde ise Kruskal-Wallis H testi kullanılmıştır. Ayrıca hangi gruplar arasında anlamlı farklılığın olduğunu belirleyebilmek için Mann-Whitney U testi ile çoklu karşılaştırmalar yapılmıştır.

Ölçekte yer alan ilgili alt maddelerden alınan puanlara ait aritmetik ortalamaların yorumlanmasında kullanılacak olan derecelendirme seçeneklerinin puanlara göre dağılımı Tablo 2' de verilmiştir.

Tablo 2. Araştırma Ölçeğindeki Derecelendirme Seçeneklerinin Puanlara Göre Dağılımı

\begin{tabular}{lccc}
\hline Seçenekler & Puanlar & Puan Aralığı & Ölçek Değerlendirme \\
\hline Hiçbir zaman & 1 & $1.00-1.80$ & Yetersiz \\
Nadiren & 2 & $1.81-2.60$ & Alt Düzey \\
Bazen & 3 & $2.61-3.40$ & Orta Düzey \\
Sık sık & 4 & $3.41-4.20$ & Üst Düzey \\
Her zaman & 5 & $4.21-5.00$ & Çok Üst Düzey \\
\hline
\end{tabular}




\section{Bulgular}

\section{Öğretmenlerin İlkokullarda Uygulanan Serbest Etkinlikler Dersine İlişkin Boyutlar} Temelinde Genel Görüşlerine Göre Bulgular

Öğretmenlerin, ilkokullarda uygulanan serbest etkinlikler dersine yönelik boyutlar temelinde genel görüşleri incelendiğinde, planlama aşamasında dikkate alınan hususlara yönelik katılımlarının en yüksek düzeyde ( $\bar{X}=4.09)$ olduğu, buna karşılık serbest etkinlikler dersinde karşılaşılan sorunlara yönelik katılımlarının ise en düşük düzeyde $(\bar{X}=3.04)$ olduğu görülmektedir. Diğer değerlendirmelerinin ise azalan bir sırada sırasıyla; serbest etkinlikler dersine dayalı olarak geliştirilen öneriler $(\bar{X}=4.02)$, serbest etkinlikler dersinin uygulanabilirliği $(\bar{X}=3.71)$ ve serbest etkinlikler dersinde yapılan etkinlik türleri $(\bar{X}=3.53)$ şeklinde olduğu anlaşılmaktadır (Tablo 3).

Tablo 3. Öğretmenlerin İlkokullarda Uygulanan Serbest Etkinlikler Dersine İlişkin Görüşlerine Ait Betimsel İstatistikler

\begin{tabular}{lccccc}
\hline Boyutlar & $\mathbf{N}$ & $\overline{\mathrm{X}}$ & $\mathbf{S S}$ & SH & Yorum \\
\hline Planlama & 372 & 4.09 & 0.59 & 0.03 & Üst düzey \\
Uygulama & 372 & 3.71 & 0.79 & 0.04 & Üst düzey \\
Etkinlikler & 372 & 3.53 & 0.60 & 0.03 & Üst düzey \\
Sorunlar & 372 & 3.04 & 0.79 & 0.04 & Orta düzey \\
Öneriler & 372 & 4.02 & 0.60 & 0.03 & Üst düzey \\
Genel Katılım & $\mathbf{3 7 2}$ & $\mathbf{3 . 6 4}$ & $\mathbf{0 . 4 0}$ & $\mathbf{0 . 0 2}$ & Üst düzey \\
\hline
\end{tabular}

Ayrıca puan ortalamaları dikkate alınarak bir değerlendirme yapıldığında, öğretmenlerin ilkokullarda uygulanan etkinlik saatlerinin planlama, uygulama, etkinlikler ve öneriler boyutlarına yönelik katılımlarının "üst düzeyde", sorunlar boyutuna yönelik katılımlarının ise "orta düzeyde" olduğu görülmektedir. Ayrıca öğretmenlerin serbest etkinlikler dersine yönelik genel değerlendirmelerini ortaya koyan katılımlarının da üst düzeyde ( $\overline{\mathrm{X}}=3.64$ ) olduğu anlaşılmaktadır (Tablo 3).

Öğretmenlerin İlkokullarda Uygulanan Serbest Etkinlikler Dersinin Planlama Aşamasına İlişkin Görüşleri

Tablo 4. Öğretmenlerin “Planlama” Boyutuna İlişkin Görüşlerinin Aritmetik Ortalama ve Standart Sapma Değerleri

\begin{tabular}{|c|c|c|c|c|}
\hline \multirow{2}{*}{ 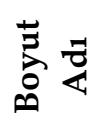 } & \multirow{2}{*}{$\sum_{\substack{\frac{\pi}{\pi} \\
\frac{\pi}{\pi}}}^{\circ}$} & \multirow{2}{*}{ Ölçek Maddeleri } & \multicolumn{2}{|c|}{ Öğretmenler } \\
\hline & & & $\overline{\mathrm{X}}$ & SS \\
\hline \multirow{3}{*}{ 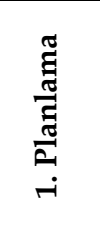 } & 1. & Dersten önce gerekli hazırlığ ilgili genelge doğrultusunda yaparım. & 3.88 & 0.94 \\
\hline & 2. & Planlamada çevre koşullarını dikkate alırım. & 4.24 & 0.80 \\
\hline & 3. & $\begin{array}{l}\text { Seçtiğim etkinliklerin düşünme becerilerini destekler nitelikte olmasına } \\
\text { dikkat ederim. }\end{array}$ & 4.23 & 0.75 \\
\hline
\end{tabular}




\begin{tabular}{|c|c|c|c|c|}
\hline & 4. & Öğrencilerin aktif olarak katılabilecekleri etkinlikler düzenlerim. & 4.27 & 0.74 \\
\hline & 5. & Ders için seçtiğim kazanımlar çocuğun yaratıcılığını destekler niteliktedir. & 4.08 & 0.78 \\
\hline & 6 & $\begin{array}{l}\text { Etkinlikleri planlarken, birden çok duyu organına hitap edecek şekilde } \\
\text { çeşitlendiririm. }\end{array}$ & 4.17 & 0.74 \\
\hline & 7. & $\begin{array}{l}\text { Planlamada öğrenciler için grup çalışmalarına yönelik etkinliklere yer } \\
\text { veririm. }\end{array}$ & 3.80 & 0.86 \\
\hline & 8. & $\begin{array}{l}\text { Etkinlikleri belirlerken öğrencilerin ilgi ve yeteneklerini dikkate almaya } \\
\text { özen gösteririm. }\end{array}$ & 4.06 & 0.80 \\
\hline & 9. & $\begin{array}{l}\text { Planlamada, öğrencilerin derse aktif olarak katılabilecekleri etkinlikleri } \\
\text { seçmeye özen gösteririm. }\end{array}$ & 4.23 & 0.75 \\
\hline & 10. & $\begin{array}{l}\text { Öğrencilerin, yaşadıkları sorunlara yönelik çözüm üretebilecekleri } \\
\text { problemlerin planlamada yer almasına dikkat ederim. }\end{array}$ & 3.98 & 0.85 \\
\hline & 11. & $\begin{array}{l}\text { Dersi planlarken öğretmen kılavuz kitabı olmadığı için internete oldukça } \\
\text { sık başvururum. }\end{array}$ & 4.02 & 1.00 \\
\hline & 12. & Okulun fiziksel özelliklerini dikkate alarak planlama yaparım. & 4.16 & 0.83 \\
\hline Toplam & & & 4.09 & 0.59 \\
\hline
\end{tabular}

Öğretmenlerin serbest etkinlikler dersinin "planlama” faktörüne ilişkin görüşleri incelendiğinde, öğretmenlerin en çok katılım gösterdikleri ifadelerin “Öğrencilerin aktif olarak katılabilecekleri etkinlikler düzenlerim." ( $\overline{\mathrm{X}}=4.27)$ ve "Planlamada çevre koşullarını dikkate alırım." ( $\overline{\mathrm{X}}=4.24)$ ifadeleri olduğu görülmektedir. Öğretmenlerin en az katılım gösterdikleri ifadelerin ise, "Planlamada öğrenciler için grup çalışmalarına yönelik etkinliklere yer veririm." ( $\bar{X}=3.80)$ ve “Dersten önce gerekli hazırlığ1 ilgili genelge doğrultusunda yaparım." ( $\bar{X}=3.88$ ) ifadelerinin olduğu anlaşılmaktadır (Tablo 4).

Öğretmenlerin İlkokullarda Uygulanan Serbest Etkinlikler Dersinin Uygulama Aşamasına İlişkin Görüşleri

Tablo 5. Öğretmenlerin “Uygulama” Boyutuna İlişkin Görüşlerinin Aritmetik Ortalama ve Standart Sapma Değerleri

\begin{tabular}{|c|c|c|c|c|}
\hline \multirow{2}{*}{$\bar{z}_{0} \bar{z}$} & \multirow{2}{*}{ 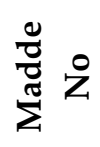 } & \multirow{2}{*}{ Ölçek Maddeleri } & \multicolumn{2}{|c|}{ Öğretmenler } \\
\hline & & & $\overline{\mathrm{X}}$ & SS \\
\hline \multirow{5}{*}{ 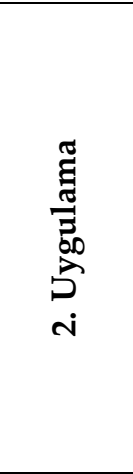 } & 13. & $\begin{array}{l}\text { Serbest etkinlik dersini planlarken, bu dersin içeriğiyle ilgili } \\
\text { genelgeyi dikkate alırım. }\end{array}$ & 3.80 & 0.97 \\
\hline & 14. & $\begin{array}{l}\text { Serbest etkinlik dersi için yapılan açıklama ve bilgilendirmeler } \\
\text { yeterlidir. }\end{array}$ & 3.20 & 1.10 \\
\hline & 15. & $\begin{array}{l}\text { Serbest etkinlik dersinin, öğrencilerin düşünme becerilerini } \\
\text { geliştirdiğini düşünüyorum. }\end{array}$ & 3.74 & 1.03 \\
\hline & 16. & $\begin{array}{l}\text { Öğrencilerin sosyal becerilerinin gelişmesine katkıda } \\
\text { bulunduğuna inanıyorum. }\end{array}$ & 3.87 & 0.98 \\
\hline & 17. & $\begin{array}{l}\text { Serbest etkinlik dersi ile öğrencilerin yaratıcı düşünme becerilerini } \\
\text { desteklerim. }\end{array}$ & 3.96 & 0.91 \\
\hline Toplan & & & 3.71 & 0.79 \\
\hline
\end{tabular}


Öğretmenlerin serbest etkinlikler dersinin "uygulama" faktörüne ilişkin görüşleri incelendiğinde, öğretmenlerin en çok katılım gösterdikleri ifadelerin "Serbest etkinlik dersi ile öğrencilerin yaratıcı düşünme becerilerini desteklerim." ( $\bar{X}=3.96)$ ve “Öğrencilerin sosyal becerilerinin gelişmesine katkıda bulunduğuna inanıyorum." ( $\overline{\mathrm{X}}=3.87)$ ifadeleri olduğu görülmektedir. Öğretmenlerin en az katılım gösterdikleri ifadelerin ise, “Serbest etkinlik dersi için yapılan açılama ve bilgilendirmeler yeterlidir." ( $\overline{\mathrm{X}}=3.20)$ ve "Serbest etkinlik dersinin, öğrencilerin düşünme becerilerini geliştirdiğini düşünüyorum" ( $\bar{X}=3.74)$ ifadelerinin olduğu anlaşılmaktadır (Tablo 5).

Öğretmenlerin İlkokullarda Uygulanan Serbest Etkinlikler Dersinde Yapılan Etkinliklere İlişkin Görüşleri

Tablo 6. Öğretmenlerin "Etkinlikler" Boyutuna İlişkin Görüşlerinin Aritmetik Ortalama ve Standart Sapma Değerleri

\begin{tabular}{|c|c|c|c|c|}
\hline \multirow{2}{*}{ 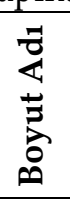 } & \multirow{2}{*}{$\begin{array}{l}0 \\
\dot{z} \\
0 \\
\tilde{z} \\
\tilde{z} \\
\tilde{\Sigma}\end{array}$} & \multirow[b]{2}{*}{ Ölçek Maddeleri } & \multicolumn{2}{|c|}{ Öğretmenler } \\
\hline & & & $\overline{\mathrm{X}}$ & SS \\
\hline \multirow{16}{*}{ 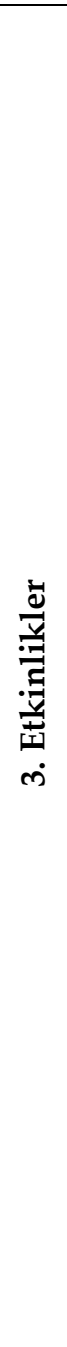 } & 18. & $\begin{array}{l}\text { Serbest etkinlik dersini planlarken hafta boyunca farklı etkinliklere } \\
\text { yer veririm. }\end{array}$ & 3.80 & 0.87 \\
\hline & 19. & $\begin{array}{l}\text { Öğrencilerde okuma alışkanlığını kazandırmaya yönelik } \\
\text { etkinlikler hazırlarım. }\end{array}$ & 4.14 & 0.76 \\
\hline & 20. & El-beceri çalışmalarını destekleyici etkinlikleri tercih ederim. & 3.69 & 0.89 \\
\hline & 21. & $\begin{array}{l}\text { Öğrencileri meslekler konusunda bilgilendirmeye yönelik } \\
\text { etkinlikler düzenlerim. }\end{array}$ & 3.53 & 0.96 \\
\hline & 22. & Masal dinleme ve anlatmaya yönelik etkinlikler yaptırırım. & 3.93 & 0.80 \\
\hline & 23. & Öğrencilere, hızlı düşünebilmeleri için tekerleme hazırlarım. & 3.64 & 0.88 \\
\hline & 24. & $\begin{array}{l}\text { Drama/dramatizasyon gibi öğrencilerde düşünme becerilerini } \\
\text { desteklemeye yönelik etkinlikler hazırlarım. }\end{array}$ & 3.54 & 0.98 \\
\hline & 25. & $\begin{array}{l}\text { Öğrencilerin gelişimlerini olumlu yönde etkileyecek eğitsel } \\
\text { oyunlara yer veririm. }\end{array}$ & 3.90 & 0.78 \\
\hline & 26. & $\begin{array}{l}\text { Güzel konuşma ve yazma alışkanlığı kazandırmaya yönelik } \\
\text { etkinlikleri tercih ederim. }\end{array}$ & 3.99 & 0.81 \\
\hline & 27. & $\begin{array}{l}\text { Film izleme ve izledikleri filmden çıarımda bulunmalarını } \\
\text { sağlamaya yönelik etkinliklere yer veririm. }\end{array}$ & 3.66 & 1.02 \\
\hline & 28. & Bilmece-bulmaca gibi etkinliklere yer veririm. & 3.92 & 0.81 \\
\hline & 29. & $\begin{array}{l}\text { Müzik dinleme ve dinledikleri müziği yorumlamalarına yönelik } \\
\text { etkinliklere yer veririm. }\end{array}$ & 3.65 & 0.85 \\
\hline & 30. & $\begin{array}{l}\text { Şiir okuma ve okuduğunu yorumlamaya yönelik etkinlikleri } \\
\text { yaptırırım. }\end{array}$ & 3.72 & 0.86 \\
\hline & 31. & Resim yapma ve boyama gibi görsel etkinlikleri tercih ederim. & 3.88 & 0.83 \\
\hline & 32. & Dersteki etkinliklerin yer aldığı sergi çalışmaları düzenlerim. & 3.06 & 1.12 \\
\hline & 33. & Gezi-gözlem çalışmaları düzenlerim. & 2.77 & 1.14 \\
\hline
\end{tabular}




\begin{tabular}{cllc}
\hline 34. & $\begin{array}{l}\text { Öğrencilerin sebze-meyve yetiştirebilecekleri ortamın } \\
\text { düzenlenmesine katkıda bulunurum. }\end{array}$ & 2.43 & 1.31 \\
35. & Halk oyunlarına yer veririm. & 2.55 & 1.24 \\
& $\begin{array}{l}\text { Diğer derslerin yetişmemesi bu saatlerin etkililiğini azaltmaktadır. } \\
\text { 36. }\end{array}$ & 3.34 & 1.11 \\
\hline Toplam & & 3.53 & $\mathbf{0 . 6 0}$ \\
\hline
\end{tabular}

Öğretmenlerin serbest etkinlikler dersinin "etkinlikler" faktörüne ilişkin görüşleri incelendiğinde, öğretmenlerin en çok katılım gösterdikleri ifadelerin “Öğrencilerde okuma alışkanlığını kazandırmaya yönelik etkinlikler hazırlarım.” ( $\bar{X}=4.14)$ ve “Güzel konuşma ve yazma alışkanlığı kazandırmaya yönelik etkinlikleri tercih ederim." ( $\bar{X}=3.99)$ ifadeleri olduğu görülmektedir. Öğretmenlerin en az katılım gösterdikleri ifadelerin ise, “Öğrencilerin sebzemeyve yetiştirebilecekleri ortamın düzenlenmesine katkıda bulunurum." ( $\overline{\mathrm{X}}=2.43$ ) ve "Halk oyunlarına yer veririm." ( $\overline{\mathrm{X}}=2.55$ ) ifadelerinin olduğu anlaşılmaktadır (Tablo 6).

Öğretmenlerin İlkokullarda Uygulanan Serbest Etkinlikler Dersinde Karşılaşılan Sorunlara İlişkin Görüşleri

Tablo 7. Öğretmenlerin "Sorunlar" Boyutuna İlişkin Görüşlerinin Aritmetik Ortalama ve Standart Sapma Değerleri

\begin{tabular}{|c|c|c|c|c|}
\hline \multirow{2}{*}{ 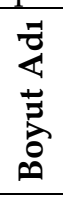 } & \multirow{2}{*}{$\begin{array}{l}0 \\
\mathbf{z} \\
\tilde{z} \\
\bar{\sigma} \\
\tilde{z}\end{array}$} & \multirow[b]{2}{*}{ Ölçek Maddeleri } & \multicolumn{2}{|c|}{ Öğretmenler } \\
\hline & & & $\overline{\mathrm{X}}$ & SS \\
\hline \multirow{12}{*}{ 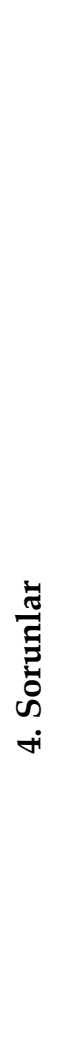 } & 37. & Serbest Etkinlik dersinde sorun yaşamam. & 3.54 & 1.05 \\
\hline & 38. & $\begin{array}{l}\text { Program çok esnek bırakıldığı için etkinlikleri seçmekte } \\
\text { zorlanırım. }\end{array}$ & 2.80 & 1.16 \\
\hline & 39. & Ders saatinin fazla olduğunu düşünüyorum. & 2.62 & 1.37 \\
\hline & 40. & $\begin{array}{l}\text { Okulun fiziki yapısının yetersizliği dersin işlenişini } \\
\text { zorlaştırmaktadır. }\end{array}$ & 3.29 & 1.30 \\
\hline & 41. & $\begin{array}{l}\text { Dersin öğretim programının olmaması kazanımları belirlememde } \\
\text { sorun yaratmaktadır. }\end{array}$ & 3.19 & 1.19 \\
\hline & 42. & $\begin{array}{l}\text { Bu derse ait bir öğretmen kılavuz kitabının bulunmaması dersin } \\
\text { planlama, uygulama ve değerlendirme aşamalarını belirlememde } \\
\text { sorun yaşamama neden olmaktadır. }\end{array}$ & 3.37 & 1.24 \\
\hline & 43. & $\begin{array}{l}\text { Okulda yeterli araç-gerecin olmaması serbest etkinlik saatlerini } \\
\text { olumsuz etkilemektedir. }\end{array}$ & 3.59 & 1.18 \\
\hline & 44. & $\begin{array}{l}\text { Sınıfların kalabalık olması dersin öğrenme-öğretme sürecini } \\
\text { olumsuz yönde etkilemektedir. }\end{array}$ & 3.55 & 1.34 \\
\hline & 45. & Öğrencilerin motivasyonunu sağlamakta zorlanırım. & 2.78 & 1.23 \\
\hline & 46. & Etkinlikleri öğrenci ilgilerine göre hazırlamakta sorun yaşarım. & 2.74 & 1.17 \\
\hline & 47. & $\begin{array}{l}\text { Bireysel farklılıklardan dolayı bazı öğrenciler etkinliklerde } \\
\text { zorlanmaktadır. }\end{array}$ & 3.21 & 1.04 \\
\hline & 48. & Serbest etkinlik dersine öğrencilerin okul kıyafetleriyle katılmaları & 2.70 & 1.34 \\
\hline
\end{tabular}


dersin etkililiğini olumsuz yönde etkilemektedir.

49. Velilerin bu derse destek olmaması, bu dersi önemsiz görmesi sorunlara yol açmaktadır.

50. Sınıf disiplinini sağlamada sorun yaşarım.

51. Serbest etkinlik dersi ile ilgili hizmet-içi seminerler

Öğretmenlerin serbest etkinlikler dersinin "sorunlar" faktörüne ilişkin görüşleri incelendiğinde, öğretmenlerin en çok katılım gösterdikleri ifadelerin “Okulda yeterli araçgerecin olmaması serbest etkinlik saatlerini olumsuz etkilemektedir." ( $\bar{X}=3.59)$ ve "Sinıfların kalabalık olması dersin öğrenme-öğretme sürecini olumsuz yönde etkilemektedir." ( $\overline{\mathrm{X}}=3.55)$ ifadeleri olduğu görülmektedir. Öğretmenlerin en az katılım gösterdikleri ifadelerin ise, “Sınıf disiplinini sağlamada sorun yaşarım." ( $\bar{X}=2.36)$ ve "Ders saatinin fazla olduğunu düşünüyorum." ( $\overline{\mathrm{X}}=2.62$ ) ifadelerinin olduğu anlaşılmaktadır (Tablo 7).

Öğretmenlerin İlkokullarda Uygulanan Serbest Etkinlikler Dersine Dayalı Olarak Geliştirilen Önerilere İlişkin Görüşleri

Tablo 8. Öğretmenlerin "Öneriler" Boyutuna İlişkin Görüşlerinin Aritmetik Ortalama ve Standart Sapma Değerleri

\begin{tabular}{|c|c|c|c|c|}
\hline \multirow{2}{*}{\begin{tabular}{l}
$\tilde{Z}$ \\
\multirow{2}{*}{} \\
\multirow{2}{*}{} \\
0
\end{tabular}} & \multirow{2}{*}{$\begin{array}{l}0 \\
z \\
\tilde{z} \\
\frac{\pi}{\sigma} \\
\Sigma\end{array}$} & \multirow[b]{2}{*}{ Ölçek Maddeleri } & \multicolumn{2}{|c|}{ Öğretmenler } \\
\hline & & & $\overline{\mathrm{X}}$ & SS \\
\hline \multirow{11}{*}{ 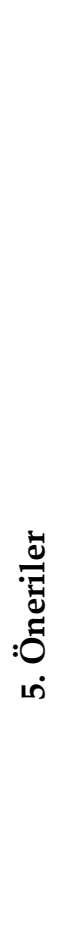 } & 52. & Ders saati azaltılmalıdır. & 2.86 & 1.36 \\
\hline & 53. & $\begin{array}{l}\text { Diğer derslerin programları, serbest etkinlik dersinin } \\
\text { eklenmesinden sonraki haftalık ders saati uygulamasına paralel } \\
\text { olarak yeniden düzenlenmelidir. }\end{array}$ & 3.45 & 1.00 \\
\hline & 54. & Bu ders için özel etkinlik mekânları düzenlenmelidir. & 4.21 & 0.84 \\
\hline & 55. & Bu dersin öğretim programı olmalıdır. & 4.11 & 0.92 \\
\hline & 56. & Öğretmen kılavuz kitabı hazırlanmalıdır. & 4.16 & 0.92 \\
\hline & 57. & $\begin{array}{l}\text { Dersin içeriğinin öğrenciler tarafından da açık olarak } \\
\text { anlaşılabilmesi için bir ders kitabının olması gerekmektedir. }\end{array}$ & 3.99 & 1.06 \\
\hline & 58. & $\begin{array}{l}\text { Dersin içeriğindeki bazı etkinlikler için branş öğretmenleri de } \\
\text { derse girebilmelidir. }\end{array}$ & 3.99 & 1.09 \\
\hline & 59. & $\begin{array}{l}\text { Etkinlikler için uygun materyal ve araç-gereçlerin temini } \\
\text { sağlanmalıdır. }\end{array}$ & 4.43 & 0.75 \\
\hline & 60. & Serbest etkinlik dersinde farklı etkinlikler düzenlenmelidir. & 4.36 & 0.80 \\
\hline & 61. & Etkinlikler öğrenci seviyesine uygun olmalıdır. & 4.47 & 0.67 \\
\hline & 62. & $\begin{array}{l}\text { Belirlenen etkinliklerin niteliğine göre farklı kurumlarla işbirliği } \\
\text { yapılarak, kurumlardan yardım alınmalıdır. }\end{array}$ & 4.19 & 0.83 \\
\hline
\end{tabular}


63. Serbest etkinlik dersine yönelik olarak hizmet-içi seminerler verilmelidir.

64. Yönetici ve velilerin serbest etkinlik dersi hakkında bilgilendirilmesi gerekmektedir.

$4.06 \quad 0.94$

Öğretmenlerin serbest etkinlikler dersinin "öneriler" faktörüne ilişkin görüşleri incelendiğinde, öğretmenlerin en çok katılım gösterdikleri ifadelerin "Etkinlikler öğrenci seviyesine uygun olmalıdır." ( $\overline{\mathrm{X}}=4.47)$ ve "Etkinlikler için uygun materyal ve araç-gereçlerin temini sağlanmalıdır." ( $\overline{\mathrm{X}}=4.43)$ ifadeleri olduğu görülmektedir. Öğretmenlerin en az katılım gösterdikleri ifadelerin ise, "Ders saati azaltılmalıdır." ( $\overline{\mathrm{X}}=2.86)$ ve "Diğer derslerin programları, serbest etkinlik dersinin eklenmesinden sonraki haftalık ders saati uygulamasına paralel olarak yeniden düzenlenmelidir." ( $\overline{\mathrm{X}}=3.45)$ ifadelerinin olduğu anlaşılmaktadır (Tablo 8).

Öğretmenlerin İlkokullarda Uygulanan Serbest Etkinlikler Dersine İlişkin Görüşlerinin Değişkenlere Göre Dağılımı

Cinsiyet Değiişkenine Göre Bulgular

Tablo 9. Öğretmenlerin İlkokullarda Uygulanan Serbest Etkinlikler Dersine İlişkin Görüşlerinin Cinsiyet Değişkenine Göre Karşılaştırılması

\begin{tabular}{llcccccc}
\hline Boyutlar & Gruplar & $\mathbf{N}$ & $\overline{\mathbf{X}}$ & $\mathbf{S S}$ & $\mathbf{S d}$ & $\mathbf{t}$ & $\mathbf{p}$ \\
\hline \multirow{3}{*}{ Planlama } & A) Kadın & 165 & 4.12 & 0.53 & 370 & 0.79 & 0.43 \\
& B) Erkek & 207 & 4.07 & 0.63 & & & \\
& Toplam & 372 & & & & & \\
Uygulama & A) Kadın & 165 & 3.65 & 0.78 & 370 & -1.37 & 0.17 \\
& B) Erkek & 207 & 3.76 & 0.79 & & & \\
Ttkinlikler & Toplam & 372 & & & & & \\
& A) Kadın & 165 & 3.51 & 0.61 & 370 & -0.77 & 0.44 \\
& B) Erkek & 207 & 3.55 & 0.59 & & & \\
Sorunlar & Toplam & 372 & & & & & \\
& A) Kadın & 165 & 3.02 & 0.78 & 370 & -0.52 & 0.60 \\
& B) Erkek & 207 & 3.06 & 0.80 & & & \\
Öneriler & Toplam & 372 & & & & & \\
& A) Kadın & 165 & 4.07 & 0.60 & 370 & 1.37 & 0.17 \\
& B) Erkek & 207 & 3.98 & 0.59 & & & \\
\hline
\end{tabular}

${ }^{*} \mathrm{p}<.05$

Öğretmenlerin ilkokullarda uygulanan serbest etkinlikler dersine ilişkin görüşlerini cinsiyet değişkeni açısından karşılaştırmak için bağımsız örneklemler için $t$ testi kullanılmıştır. Analiz sonuçlarına göre, öğretmenlerin; planlama $\left[\mathrm{t}_{(370)}=0.79, \mathrm{p}>.05\right]$, uygulama [ $\left.\mathrm{t}_{(370)}=-1.37, \mathrm{p}>.05\right]$, etkinlikler $\left[\mathrm{t}_{(370)}=-0.77, \mathrm{p}>.05\right]$, sorunlar $\left[\mathrm{t}_{(370)}=-0.52, \mathrm{p}>.05\right]$ ve 
öneriler $\left[\mathrm{t}_{(370)}=1.37, \mathrm{p}>\right.$.05] boyutlarında görüşleri arasında cinsiyet değişkeni açısından anlamlı bir farklılık görülmemiştir. Bu bulgu, öğretmenlerin ilkokullarda uygulanan serbest etkinlikler dersine ilişkin görüşleri ile cinsiyet değişkeni arasında anlamlı bir ilişkinin olmadı̆̆ını göstermektedir (Tablo 9).

Ancak katılımcı grupların görüşleri puan ortalamaları açısından değerlendirildiğinde, erkek ve kadın öğretmenlerin görüşleri birbirine yakın olmakla birlikte, kadın öğretmenlerin planlama ve öneriler boyutlarına, erkek öğretmenlerin ise uygulama, etkinlikler ve sorunlar boyutlarına ilişkin katılımlarının daha yüksek düzeyde olduğu görülmektedir. Ayrıca, hem kadın hem de erkek öğretmenlerin planlama, uygulama, etkinlikler ve öneriler boyutlarına ilişkin katılımlarının "üst düzeyde", sorunlar boyutuna ilişkin katılımlarının ise "orta düzeyde" olduğu anlaşılmaktadır (Tablo 9).

\section{Mesleki Kıdem Değişkenine Göre Bulgular}

Tablo 10. Öğretmenlerin İlkokullarda Uygulanan Serbest Etkinlikler Dersine İlişkin Görüşlerinin Mesleki Kıdem Değişkenine Göre Karşılaştırılması

\begin{tabular}{|c|c|c|c|c|c|c|c|c|c|c|}
\hline Boyutlar & Gruplar & $\mathrm{N}$ & $\bar{X}$ & $\begin{array}{c}\text { Varyansın } \\
\text { Kaynağ1 }\end{array}$ & $\begin{array}{l}\text { Kareler } \\
\text { Toplamı }\end{array}$ & Sd & $\begin{array}{c}\text { Kareler } \\
\text { Ortalaması }\end{array}$ & $\mathrm{F}$ & $\mathrm{p}$ & $\begin{array}{c}\text { Anlamli } \\
\text { fark } \\
\text { (Scheffe) }\end{array}$ \\
\hline \multirow{7}{*}{ Planlama } & A) 1-5 yıl arası & 47 & 3.97 & \multirow{3}{*}{$\begin{array}{l}\text { Gruplar } \\
\text { arası }\end{array}$} & \multirow{3}{*}{1.298} & \multirow{3}{*}{5} & \multirow{3}{*}{.260} & \multirow{7}{*}{0.76} & \multirow{7}{*}{0.58} & \multirow{7}{*}{-} \\
\hline & B) 6-10 yıl arası & 74 & 4.07 & & & & & & & \\
\hline & C) $11-15$ y1l arası & 82 & 4.16 & & & & & & & \\
\hline & D) $16-20$ y1l arası & 76 & 4.10 & \multirow{4}{*}{$\begin{array}{l}\text { Gruplar } \\
\text { içi }\end{array}$} & \multirow{3}{*}{125.780} & \multirow{3}{*}{366} & \multirow{4}{*}{.344} & & & \\
\hline & E) $21-25$ yıl arası & 64 & 4.13 & & & & & & & \\
\hline & F) 26 yıl ve üzeri & 29 & 4.05 & & & & & & & \\
\hline & Toplam & 372 & 4.09 & & 127.078 & 371 & & & & \\
\hline \multirow{7}{*}{ Uygulama } & A) $1-5$ yıl arası & 47 & 3.66 & \multirow{3}{*}{$\begin{array}{l}\text { Gruplar } \\
\text { arası }\end{array}$} & \multirow{3}{*}{.686} & \multirow{3}{*}{5} & \multirow{3}{*}{.137} & \multirow{7}{*}{0.22} & \multirow{7}{*}{0.95} & \multirow{7}{*}{-} \\
\hline & B) 6-10 yıl arası & 74 & 3.70 & & & & & & & \\
\hline & C) $11-15$ y1l arası & 82 & 3.67 & & & & & & & \\
\hline & D) $16-20$ y1l arası & 76 & 3.77 & \multirow{4}{*}{$\begin{array}{l}\text { Gruplar } \\
\text { içi }\end{array}$} & \multirow{3}{*}{229.777} & \multirow{3}{*}{366} & \multirow{4}{*}{.628} & & & \\
\hline & E) $21-25$ yıl arası & 64 & 3.76 & & & & & & & \\
\hline & F) 26 yıl ve üzeri & 29 & 3.70 & & & & & & & \\
\hline & Toplam & 372 & 3.71 & & 230.463 & 371 & & & & \\
\hline \multirow{7}{*}{ Etkinlikler } & A) $1-5$ yıl aras 1 & 47 & 3.46 & \multirow{3}{*}{$\begin{array}{l}\text { Gruplar } \\
\text { aras1 }\end{array}$} & \multirow{3}{*}{1.103} & \multirow{3}{*}{5} & \multirow{3}{*}{.221} & \multirow{7}{*}{0.61} & & \\
\hline & B) 6-10 yıl arası & 74 & 3.49 & & & & & & & \\
\hline & C) $11-15$ y1l aras 1 & 82 & 3.57 & & & & & & & \\
\hline & D) $16-20$ y1l aras 1 & 76 & 3.54 & & & & & & 0.69 & - \\
\hline & E) $21-25$ yıl arası & 64 & 3.52 & Gruplar & 132.980 & 366 & .363 & & & \\
\hline & F) 26 yıl ve üzeri & 29 & 3.67 & & & & & & & \\
\hline & Toplam & 372 & 3.53 & & 134.083 & 371 & & & & \\
\hline & A) $1-5$ y1l aras 1 & 47 & 2.97 & & & & & & & \\
\hline Sorunlar & B) 6-10 yıl arası & 74 & 3.07 & $\begin{array}{l}\text { Gruplar } \\
\text { aras1 }\end{array}$ & 1.927 & 5 & .385 & & & \\
\hline & C) $11-15$ yil arası & 82 & 3.20 & & & & & 0.61 & 0.69 & - \\
\hline & D) $16-20$ y1l arası & 76 & 3.02 & Gruplar & חבר 231 & 366 & 621 & & & \\
\hline & E) $21-25$ yıl arası & 64 & 2.99 & içi & 201.020 & 300 & - .031 & & & \\
\hline
\end{tabular}




\begin{tabular}{|c|c|c|c|c|c|c|c|c|c|c|}
\hline & \multirow{2}{*}{$\begin{array}{l}\text { F) } 26 \text { yıl ve üzeri } \\
\text { Toplam }\end{array}$} & \multirow{2}{*}{$\begin{array}{c}29 \\
372 \\
\end{array}$} & 3.10 & & & & & & & \\
\hline & & & 3.04 & & 232.947 & 371 & & & & \\
\hline \multirow{7}{*}{ Öneriler } & A) 1-5 yıl arası & 47 & 3.97 & \multirow{3}{*}{$\begin{array}{l}\text { Gruplar } \\
\text { aras1 }\end{array}$} & \multirow{3}{*}{.868} & \multirow{3}{*}{5} & \multirow{3}{*}{.174} & \multirow{7}{*}{0.48} & \multirow{7}{*}{0.79} & \\
\hline & B) 6-10 y1l aras1 & 74 & 3.98 & & & & & & & \\
\hline & C) $11-15$ yıl arası & 82 & 4.04 & & & & & & & \\
\hline & D) $16-20$ yıl arasi & 76 & 3.98 & \multirow{4}{*}{$\begin{array}{l}\text { Gruplar } \\
\text { içi }\end{array}$} & \multirow{3}{*}{131.574} & \multirow{3}{*}{366} & \multirow{4}{*}{.359} & & & - \\
\hline & E) $21-25$ yıl arası & 64 & 4.10 & & & & & & & \\
\hline & F) 26 yıl ve üzeri & 29 & 4.06 & & & & & & & \\
\hline & Toplam & 372 & 4.02 & & 132.442 & 371 & & & & \\
\hline
\end{tabular}

$* \mathrm{p}<.05$

Farklı 5 mesleki kıdeme göre gruplandırılan öğretmenlerin, ilkokullarda uygulanan serbest etkinlik derslerine ilişkin görüşleri arasında anlamlı fark olup olmadığını sınamak için, mesleki kıdemlerine göre oluşturulan grupların görüşlerinin ortalamaları ilişkisiz örneklemler için tek yönlü varyans analizi (ANOVA) ile karşılaştırılmıştır. Analiz sonuçları, planlama $[F(5,366)=0.76, p>.05]$, uygulama $[F(5,366)=0.22$ p $>.05]$, etkinlikler $[F(5,366)=0.61$, $\mathrm{p}>.05]$, sorunlar $[\mathrm{F}(5,366)=0.61, \mathrm{p}>.05]$ ve öneriler $[\mathrm{F}(5,366)=0.48, \mathrm{p}>.05]$ boyutlarinda öğretmen görüşleri arasında mesleki kıdemleri bakımından istatistiksel olarak anlamlı bir fark olmadığını göstermektedir. Başka bir deyişle, öğretmenlerin ilkokullarda uygulanan serbest etkinlikler dersine ilişkin görüşleri, mesleki kıdemlerine bağlı olarak anlamlı bir şekilde farklılaşmamaktadır.

Ayrıca, öğretmenlerin puan ortalamaları dikkate alınarak bir değerlendirme yapıldığında, 1-5 yıl arası mesleki kıdem grubundaki öğretmenlerin diğer kıdem gruplarında yer alan öğretmenlere nazaran ilkokullarda uygulanan serbest etkinlikler dersini değerlendirmeye yönelik tüm boyutlardaki katılımlarının daha düşük düzeyde olduğu anlaşılmaktadır (Tablo 10).

\section{Sinıf Mevcudu Değişkenine Göre Bulgular}

Tablo 11. Öğretmenlerin İlkokullarda Uygulanan Serbest Etkinlikler Dersine İlişkin Görüşlerinin Sınıf Mevcudu Değişkenine Göre Karşılaştırılması

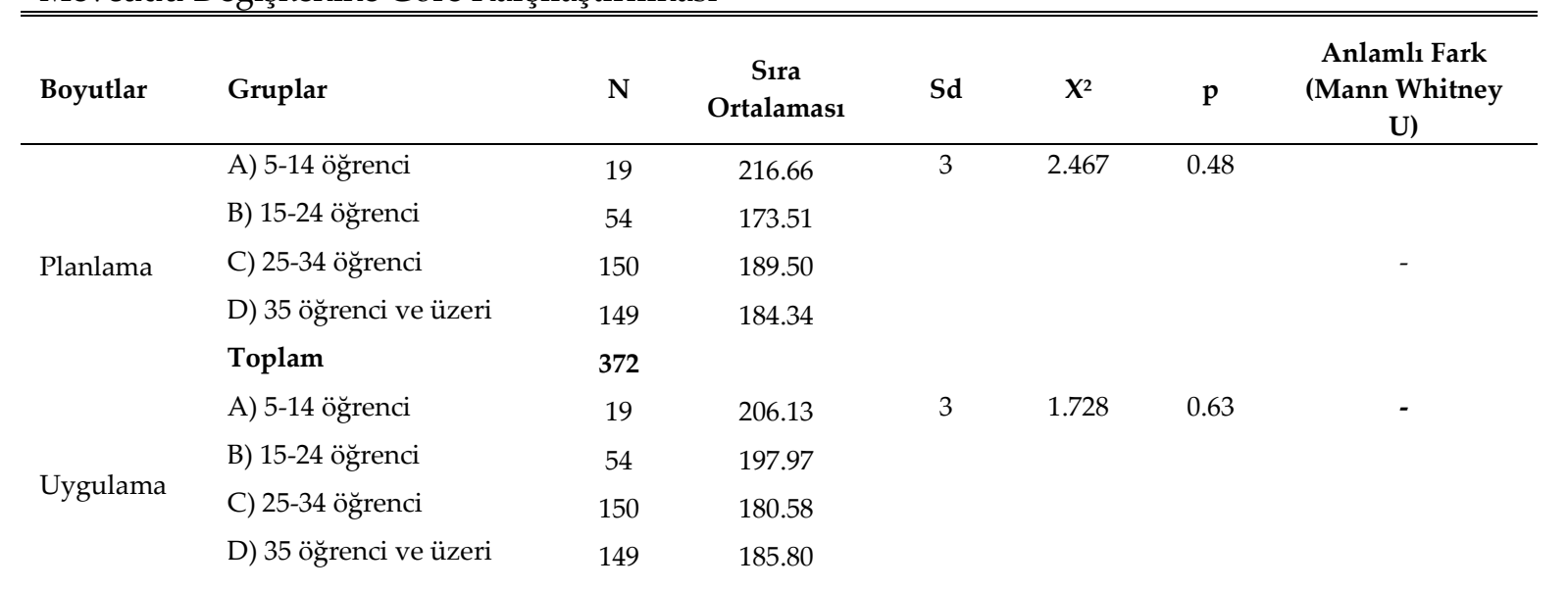




\begin{tabular}{|c|c|c|c|c|c|c|c|}
\hline & Toplam & 372 & & & & & \\
\hline \multirow{5}{*}{ Etkinlikler } & A) 5-14 öğrenci & 19 & 202.21 & 3 & 4.022 & 0.26 & - \\
\hline & B) 15-24 öğrenci & 54 & 182.61 & & & & \\
\hline & C) 25-34 öğrenci & 150 & 174.54 & & & & \\
\hline & D) 35 öğrenci ve üzeri & 149 & 197.94 & & & & \\
\hline & Toplam & 372 & & & & & \\
\hline \multirow{5}{*}{ Sorunlar } & A) 5-14 öğrenci & 19 & 192.16 & 3 & 22.785 & $0.00^{*}$ & D-B \\
\hline & B) 15-24 öğrenci & 54 & 156.64 & & & & D-C \\
\hline & C) 25-34 öğrenci & 150 & 165.31 & & & & \\
\hline & D) 35 öğrenci ve üzeri & 149 & 217.93 & & & & \\
\hline & Toplam & 372 & & & & & \\
\hline \multirow{5}{*}{ Öneriler } & A) 5-14 öğrenci & 19 & 195.58 & 3 & 3.174 & 0.37 & - \\
\hline & B) 15-24 öğrenci & 54 & 165.50 & & & & \\
\hline & C) 25-34 öğrenci & 150 & 186.54 & & & & \\
\hline & D) 35 öğrenci ve üzeri & 149 & 177.21 & & & & \\
\hline & Toplam & 372 & & & & & \\
\hline
\end{tabular}

Farklı 4 sınıf mevcudu kategorisine göre gruplandırılan öğretmenlerin, ilkokullarda uygulanan serbest etkinlikler dersine ilişkin görüşleri arasında anlamlı fark olup olmadığını sınamak için, Kruskal-Wallis H testi kullanılmıştır. Analiz sonuçlarına göre, öğretmenlerin serbest etkinlikler dersine ilişkin sorunlar $\left[X^{2}(3)=22.785, p<.05\right]$ boyutundaki görüşleri arasında anlamlı bir farklılık görülmektedir. Mann Whitney-U testi ile yapılan çoklu karşılaştırmalar neticesinde bu farkın, sınıf mevcudu 35 öğrenci ve üzeri olan öğretmenler ile sinıf mevcudu 15-24 öğrenci ve 25-34 öğrenci olanlar arasında olduğu görülmektedir. Buna göre, sınıf mevcudu 35 öğrenci ve üzeri olan öğretmenlerin, diğer sınıf mevcutlarına sahip öğretmenlere nazaran serbest etkinlikler dersinde daha çok sorunla karşılaştıklarını ifade ettikleri anlaşılmaktadır.

İlkokullarda uygulanan serbest etkinlikler dersine dair diğer boyutlar olan planlama $\left[\mathrm{X}^{2}(3)=2.467, \mathrm{p}>.05\right]$, uygulama $\left[\mathrm{X}^{2}(3)=1.728, \mathrm{p}>.05\right]$, etkinlikler $\left[\mathrm{X}^{2}(3)=4.022, \mathrm{p}>.05\right]$ ve öneriler $\left[\mathrm{X}^{2}(3)=3.174, \mathrm{p}>.05\right]$ boyutlarında katılımcı grupların görüşleri arasında sınıf mevcutları bakımından anlamlı farklılık görülmemektedir (Tablo 11). Grupların sıra ortalamaları dikkate alındığında, sınıf mevcudu 5-14 öğrenci olan öğretmenlerin diğer sınıf mevcutlarına sahip öğretmenlere nazaran planlama, uygulama, etkinlikler ve öneriler boyutlarındaki sıra ortalamalarının daha yüksek olduğu görülmektedir. Buna göre, sınıf mevcudu az olan öğretmenlerin (5-14 öğrenci) ilkokullarda uygulanan serbest etkinlikler dersine ilişkin planlama, uygulama, etkinlikler ve öneriler boyutlarındaki değerlendirmelerinin daha yüksek düzeyde olduğu anlaşılmaktadır (Tablo 11).

Okuttuğu Sınıf Düzeyi Değişkenine Göre Bulgular 
Tablo 12. Öğretmenlerin İlkokullarda Uygulanan Serbest Etkinlikler Dersine İlişkin Görüşlerinin Okuttuğu Sınıf Düzeyi Değişkenine Göre Karşılaştırılması

\begin{tabular}{|c|c|c|c|c|c|c|c|c|c|c|}
\hline Boyutlar & Gruplar & $\mathrm{N}$ & $\mathrm{X}$ & $\begin{array}{c}\text { Varyansın } \\
\text { Kaynağı }\end{array}$ & $\begin{array}{l}\text { Kareler } \\
\text { Toplamı }\end{array}$ & $\mathrm{Sd}$ & $\begin{array}{c}\text { Kareler } \\
\text { Ortalaması }\end{array}$ & $\mathrm{F}$ & $\mathrm{p}$ & $\begin{array}{c}\text { Anlamli } \\
\text { fark } \\
\text { (Scheffe) }\end{array}$ \\
\hline \multirow{4}{*}{ Planlama } & A) $1 . \sin 1 f$ & 116 & 4.05 & Gruplar & 252 & 2 & 176 & \multirow{4}{*}{0.51} & \multirow{4}{*}{0.60} & \multirow{4}{*}{ - } \\
\hline & B) 2.sinif & 130 & 4.10 & arası & & 2 & .170 & & & \\
\hline & C) $3 . \sin 1 f$ & 126 & 4.12 & $\begin{array}{l}\text { Gruplar } \\
\text { içi }\end{array}$ & 126.726 & 369 & .343 & & & \\
\hline & Toplam & 372 & 3.58 & & 127.078 & 371 & & & & \\
\hline \multirow{4}{*}{ Uygulama } & A) 1.sinif & 116 & 3.58 & Gruplar & 2076 & 2 & 1100 & \multirow{4}{*}{2.41} & \multirow{4}{*}{0.09} & \multirow{4}{*}{ - } \\
\hline & B) 2.sinif & 130 & 3.75 & arası & 2.916 & 2 & 1.488 & & & \\
\hline & C) $3 . \sin 1 f$ & 126 & 3.80 & $\begin{array}{l}\text { Gruplar } \\
\text { içi }\end{array}$ & 227.487 & 369 & 0.616 & & & \\
\hline & Toplam & 372 & 3.71 & & 230.463 & 371 & & & & \\
\hline \multirow{4}{*}{ Etkinlikler } & A) $1 . \sin ı f$ & 116 & 3.44 & Gruplar & 1534 & 2 & 0767 & \multirow{4}{*}{2.14} & \multirow{4}{*}{0.12} & \multirow{4}{*}{-} \\
\hline & B) 2.sinif & 130 & 3.56 & arası & 1.034 & 2 & 0.708 & & & \\
\hline & C) 3.sinif & 126 & 3.59 & $\begin{array}{l}\text { Gruplar } \\
\text { içi }\end{array}$ & 132.549 & 369 & 0.359 & & & \\
\hline & Toplam & 372 & 3.53 & & 134.083 & 371 & & & & \\
\hline \multirow{4}{*}{ Sorunlar } & A) 1.sinif & 116 & 3.04 & Gruplar & 031 & 2 & 0465 & \multirow{4}{*}{0.74} & \multirow{4}{*}{0.48} & \multirow{4}{*}{-} \\
\hline & B) $2 . \operatorname{sinif}$ & 130 & 2.98 & aras1 & גטונ. & 2 & 0.700 & & & \\
\hline & C) $3 . \sin 1 f$ & 126 & 3.10 & $\begin{array}{l}\text { Gruplar } \\
\text { içi }\end{array}$ & 232.016 & 369 & 0.629 & & & \\
\hline & Toplam & 372 & 3.04 & & 232.947 & 371 & & & & \\
\hline \multirow{4}{*}{ Öneriler } & A) 1.sinif & 116 & 4.06 & Gruplar & 1038 & 2 & 0519 & \multirow{4}{*}{1.46} & \multirow{4}{*}{0.23} & \multirow{4}{*}{-} \\
\hline & B) $2 . \operatorname{sinif}$ & 130 & 3.95 & arası & 1.000 & 2 & 0.319 & & & \\
\hline & C) $3 . \sin 1 f$ & 126 & 4.06 & $\begin{array}{l}\text { Gruplar } \\
\text { içi }\end{array}$ & 131.404 & 369 & 0.356 & & & \\
\hline & Toplam & 372 & 4.02 & & 132.442 & 371 & & & & \\
\hline
\end{tabular}

${ }^{*} \mathrm{p}<.05$

Farklı 3 sinıf düzeyine göre gruplandırılan öğretmenlerin, ilkokullarda uygulanan serbest etkinlikler dersine ilişkin görüşleri arasında anlamlı fark olup olmadığını sınamak için, okuttukları sınıf düzeylerine göre oluşturulan grupların görüşlerinin ortalamaları ilişkisiz örneklemler için tek yönlü varyans analizi (ANOVA) ile karşılaştırılmıştır. Analiz sonuçları, planlama $[F(2,369)=0.51, p>.05]$, uygulama $[F(2,369)=2.41$ p $>.05]$, etkinlikler $[F(2$, $369)=2.14, \mathrm{p}>.05]$, sorunlar $[\mathrm{F}(2,369)=0.74, \mathrm{p}>.05]$ ve öneriler $[\mathrm{F}(2,369)=1.46, \mathrm{p}>.05]$ boyutlarında öğretmen görüşleri arasında okuttukları sınıf düzeyleri bakımından istatistiksel olarak anlamlı bir fark olmadığını göstermektedir. (Tablo 12). 
Mezun Olunan Fakülte Değişkenine Göre Bulgular

Tablo 13. Öğretmenlerin İlkokullarda Uygulanan Serbest Etkinlikler Dersine İlişkin Görüşlerinin Mezun Olunan Fakülte Değişkenine Göre Karşılaştırılması

\begin{tabular}{llllllll}
\hline Boyutlar & Gruplar & $\mathrm{N}$ & $\overline{\mathrm{X}}$ & $\mathrm{SS}$ & $\mathrm{sd}$ & $\mathrm{t}$ & $\mathrm{P}$ \\
\hline Planlama & A) Eğitim Fakültesi & 323 & 4.09 & 0.58 & 370 & 0.06 & 0.96 \\
& B) Diğer & 49 & 4.09 & 0.64 & & & \\
Uygulama & A) Eğitim Fakültesi & 323 & 3.70 & 0.78 & 370 & -0.87 & 0.83 \\
& B) Diğer & 49 & 3.80 & 0.81 & & & \\
Etkinlikler & A) Eğitim Fakültesi & 323 & 3.53 & 0.60 & 370 & -0.48 & 0.63 \\
& B) Diğer & 49 & 3.57 & 0.64 & & & \\
Sorunlar & A) Eğitim Fakültesi & 323 & 3.06 & 0.78 & 370 & 0.95 & 0.34 \\
& B) Diğer & 49 & 2.94 & 0.87 & & & \\
Öneriler & A) Eğitim Fakültesi & 323 & 4.02 & 0.59 & 370 & 0.43 & 0.66 \\
& B) Diğer & 49 & 3.98 & 0.63 & & & \\
\hline${ }^{*} \mathrm{p}<.05$ & & & & & & &
\end{tabular}

Öğretmenlerin ilkokullarda uygulanan serbest etkinlikler dersine ilişkin görüşlerini mezun olunan fakülte değişkeni açısından karşılaştırmak için bağımsız örneklemler için $t$ testi kullanılmıştır. Analiz sonuçlarına göre, öğretmenlerin; planlama [ $\left.\mathrm{t}_{(370)}=0.06, \mathrm{p}>.05\right]$, uygulama $\left[\mathrm{t}_{(370)}=-0.87, \mathrm{p}>.05\right]$, etkinlikler $\left[\mathrm{t}_{(370)}=-0.48, \mathrm{p}>.05\right]$, sorunlar $\left[\mathrm{t}_{(370)}=0.95, \mathrm{p}>.05\right]$ ve öneriler [ $\left.\mathrm{t}_{(370)}=0.43, \mathrm{p}>.05\right]$ boyutlarında görüşleri arasında mezun olunan fakülte değişkeni açısından anlamlı bir farklılık görülmemiştir. Ancak katılımcı grupların görüşleri puan ortalamaları açısından değerlendirildiğinde, Eğitim Fakültesi ve Diğer fakültelerden mezun olan öğretmenlerin görüşleri birbirine yakın olmakla birlikte, Diğer fakültelerden mezun olan öğretmenlerin uygulama ve etkinlikler boyutlarına, Eğitim Fakültesi mezunu öğretmenlerin ise sorunlar ve öneriler boyutlarına ilişkin katılımlarının daha yüksek düzeyde olduğu görülmektedir. Ayrıca, her iki grupta yer alan öğretmenlerin planlama, uygulama, etkinlikler ve öneriler boyutlarına ilişkin katılımlarının "üst düzeyde", sorunlar boyutuna ilişkin katılımlarının ise "orta düzeyde" olduğu anlaşılmaktadır (Tablo 13).

\section{Lisansüstü Eğitim Alma Durumuna Göre Bulgular}

Tablo 14. Öğretmenlerin İlkokullarda Uygulanan Serbest Etkinlikler Dersine İlişkin Görüşlerinin Lisansüstü Eğitim Alma Durumuna Göre Karşılaştırılması

\begin{tabular}{llllllll}
\hline Boyutlar & Gruplar & $\mathrm{N}$ & $\overline{\mathrm{X}}$ & $\mathrm{SS}$ & $\mathrm{sd}$ & $\mathrm{t}$ & $\mathrm{p}$ \\
\hline \multirow{3}{*}{ Planlama } & A) Evet & 31 & 4.34 & 0.48 & 370 & 2.46 & $0.01^{*}$ \\
& B) Hayır & 341 & 4.07 & 0.59 & & & \\
Uygulama & A) Evet & 31 & 3.99 & 0.71 & 370 & 2.08 & $0.04^{*}$ \\
& B) Hayir & 341 & 3.69 & 0.79 & & & \\
Etkinlikler & A) Evet & 31 & 3.78 & 0.76 & 370 & 1.96 & 0.06
\end{tabular}




\begin{tabular}{|c|c|c|c|c|c|c|c|}
\hline \multirow[b]{3}{*}{ Sorunlar } & \multirow[b]{2}{*}{ A) Evet } & & & & \multicolumn{3}{|c|}{ Saraçoğlu \& Çift } \\
\hline & & 31 & 2.90 & 0.91 & 370 & -1.06 & 0.29 \\
\hline & B) Hayır & 341 & 3.05 & 0.78 & & & \\
\hline & A) Evet & 31 & 4.04 & 0.62 & 370 & -0.06 & 0.95 \\
\hline Öneriler & B) Hayır & 341 & 4.01 & 0.60 & & & \\
\hline
\end{tabular}

${ }^{*} \mathrm{p}<.05$

Öğretmenlerin, ilkokullarda uygulanan serbest etkinlikler dersine ilişkin görüşlerinin lisansüstü eğitim alma durumlarına göre farklılık gösterip göstermediğini belirlemek için yapılan bağımsız örneklemler için t testine göre, "planlama" boyutunda lisansüstü eğitim alan öğretmenlerin test puan ortalamaları $\left(\overline{\mathrm{X}}_{\mathrm{A}}=4.34\right)$ ile lisansüstü eğitim almayan öğretmenlerin test puan ortalamaları $\left(\overline{\mathrm{X}}_{\mathrm{B}}=4.07\right)$ arasında, lisansüstü eğitim alan öğretmenlerin lehine anlamlı bir farklılık görülmüsstür $\left[\mathrm{t}_{(370)}=2.46, \mathrm{p}<.05\right]$. Aynı doğrultuda, "uygulama" boyutunda da lisansüstü eğitim alan öğretmenlerin test puan ortalamaları $\left(\overline{\mathrm{X}}_{\mathrm{A}}=\right.$ 3.99) ile lisansüstü eğitim almayan öğretmenlerin test puan ortalamaları $\left(\overline{\mathrm{X}}_{\mathrm{B}}=3.69\right)$ arasında, lisansüstü eğitim alan öğretmenlerin lehine anlamlı bir farklılık görülmüştür $\left[\mathrm{t}_{(370)}=2.08\right.$, p<.05]. Söz konusu bulgular, öğretmenlerin serbest etkinlikler dersinin planlama ve uygulama boyutlarına ilişkin değerlendirmeleri ile lisansüstü eğitim alma durumları arasında anlamlı bir ilişkinin olduğunu göstermektedir. Buna göre, lisansüstü eğitim alan öğretmenlerin, bu eğitimi almayan öğretmenlere nazaran serbest etkinlik saatlerinin planlama ve uygulama boyutlarına ilişkin katılımlarının daha yüksek düzeyde olduğu anlaşılmaktadır.

Diğer boyutlar olan; etkinlikler $\left[\mathrm{t}_{(370)}=1.96, \mathrm{p}>.05\right]$, sorunlar $\left[\mathrm{t}_{(370)}=-1.06, \mathrm{p}>.05\right]$ ve öneriler [ $\left.\mathrm{t}_{(370)}=-0.06, \mathrm{p}>.05\right]$ boyutlarında öğretmen görüşleri arasında lisansüstü eğitim alma durumları açısından anlamlı bir farklılık görülmemiştir. Ancak katılımcı grupların görüşleri puan ortalamaları açısından değerlendirildiğinde, her iki katılımcı grupta yer alan öğretmenlerin görüşleri birbirine yakın olmakla beraber, lisansüstü eğitim alan öğretmenlerin etkinlikler ve öneriler boyutlarına, lisansüstü eğitim almayan öğretmenlerin ise sorunlar boyutuna ilişkin katılımlarının daha yüksek düzeyde olduğu görülmektedir (Tablo 14).

\section{Tartışma, Sonuç ve Öneriler}

2010 yılından itibaren ilköğretim haftalık ders çizelgesinde yer alan serbest etkinlikler dersinin okullarda nasıl planlanıp, uygulandığı, hangi etkinliklere yer verildiği, uygulama sırasında karşılaşılan güçlükler ve sınıf öğretmenlerinin serbest etkinlikler dersi ile ilgili 
önerilerinin neler olduğuna dair sorulara bu araştırmada cevaplar aranmaya çalışılmıştır. Serbest etkinlikler dersi ile ilgili sınıf öğretmenlerinin uygulamaya yönelik görüşleri, ilk elden sağlıklı ve güvenilir bilgi alma noktasında büyük öneme sahiptir. Bu çalışma kapsamında, ilkokul 1, 2 ve 3. sınıflarda görev yapan sınıf öğretmenlerinin serbest etkinlikler dersini uygulamalarına yönelik görüşlerinin cinsiyet, kıdem, sınıf mevcudu, sınıf düzeyi, mezun olunan fakülte ve eğitim düzeyleri değişkenlerine göre farklılaşıp farklılaşmadığı araştırılmıştır.

Serbest etkinlikler dersinin değerlendirilmesine yönelik olarak boyutlar genel olarak incelendiğinde öğretmenlerin "sık sık" düzeyinde görüş belirttikleri görülmektedir. Sınıf öğretmenleri planlama, uygulama, öneriler, etkinlikler boyutuna "sık sık" şeklinde görüş belirtirlerken, sorunlar boyutunda "bazen" şeklinde görüş belirtmişlerdir. Burada öğretmenlerin serbest etkinlikler dersinin uygulanmasına yönelik çaba harcadıkları ve olumlu düşüncelere sahip oldukları söylenebilir. Benzer şekilde Yılmaz-Gündüz (2014), Gün (2013), Aydın, Bakırcı ve Ürey (2012), Dündar ve Karaca (2011) da çalışmalarında serbest etkinlikler dersi ile ilgili öğretmenlerin olumlu düşünceler içerisinde olduklarını tespit etmişlerdir.

Planlama boyutunda öğretmenlerin "sık sık" şeklinde görüş belirttikleri görülmüştür. $\mathrm{Bu}$ da öğretmenlerin serbest etkinlikler dersi ile ilgili gerekli hazırlık çalışmalarını yaptıklarını göstermektedir. Öğretmenler planlama boyutunda en fazla öğrencilerin aktif olarak yer alacakları etkinliklere yer verdiklerini ve dersi planlarken çevre koşullarını dikkate aldıklarını belirtmişlerdir. Ayrıca öğrencilerin birçok duyu organına hitap edecek, yaratıcılıklarını ve düşünme becerilerini geliştirecek etkinliklere yer verdiklerini belirtmişlerdir. Öğretmenler "ilgili genelge doğrultusunda hazırlık yapma" ve "grup çalışmalarına yer verme ifadelerine" en az düzeyde katılım göstermişlerdir. Bu da öğretmenlerin serbest etkinlikler dersi ile ilgili ön hazırlık yaparken genelgeyi çok fazla dikkate almadıklarını göstermektedir. Ayrıca grup çalışmalarına daha az yer verdikleri görülmektedir. Şen ve Sarıkaya (2015a) da öğrenci sayıları arttıkça grup tartışmaları etkinliği kullanımının azaldığını belirtmiştir. Ayrıca öğretmenler kılavuz kitap olmadığından dolayı etkinlikleri planlarken internetten destek aldıklarını belirtmişlerdir. Kazu ve Aslan (2013), Özsel (2016) araştırmalarında öğretmenlerin serbest etkinlikler dersi ile ilgili planları internetten hazır indirdiklerini, herhangi bir katkı sunmadan gerekli hazırlık çalışmalarını yapmadan dersi işlediklerini, planlamada çevre koşullarını dikkate almadıklarını, kılavuz 
kitap ve belli bir programın olmayışından dolayı dersi planlamada sorunlar yaşandığını belirtmişlerdir. Aynı şekilde Bektaş ve Dinçer (2011) de serbest etkinlikler dersinin belli bir programının olmamasından dolayı planlama aşamasında sorunlar yaşandığını belirtmişlerdir.

Serbest etkinlikler dersinin uygulanması boyutuna öğretmenler "sık sık" şeklinde olumlu düşünceler belirtmişlerdir. Bu bulgu dersin etkili olduğu sonucunu ortaya çıkarmaktadır. Serbest etkinlikler dersinin uygulama boyutunda öğretmenler bu derste öğrencilerin yaratıcı özelliklerini geliştirecek etkinliklere yer verdiklerini belirtmişlerdir. Ayrıca serbest etkinlikler dersinin öğrencilerin sosyal becerilerini geliştirdiğine inanmaktadırlar. Alanyazına göre serbest etkinlikler dersi öğrencilerin yaratıcı düşünme becerilerini geliştirmekte, öğrencilerin gelişimlerine katkı sağlamakta, sosyalleşmelerini sağlamakta, akademik başarılarını arttırmakta, güven duygusu kazanmalarına yardımcı olmakta, öğrencilerin kendilerini ifade etmelerini, eksiklerini tamamlamalarını, kendilerini tanımalarını, kendilerini rahat hissetmelerini, kendi ilgi ve yeteneklerinin farkına varmalarını, kelime dağarcıklarının gelişmesini, kişiliklerinin, yaratıcılıklarının ve özgüvenlerinin gelişmesini sağlamaktadır (Bozpolat, 2016; Gömleksiz \& Özdaş, 2013; Özsel, 2016). Aydemir, Bozkurt ve Şekerci (2015) serbest etkinlikler dersinin öğrencilerin sosyal yaşam becerilerini geliştirdiğini, yeteneklerini ortaya çıkardığını, empati kurma, iletişim, özgüven ve liderlik becerilerini geliştirdiğini belirtmişlerdir. Aydın vd. (2012) serbest etkinlikler dersinde yapılan uygulamalarla diğer derslerde yorulan öğrencilerin dinlendiğini, okula ve derslere karşı olumlu tutum geliştirdiklerini, sosyalleştiklerini, paylaşım duygularının geliştiğini, yaparak yaşayarak öğrenme fırsatı bulduklarını belirtmiştir. Bu bulguların aksine Demir (2016) çalışmasında serbest etkinlikler dersinde gerçekleştirilen etkinliklerin amacına ulaşamamasından dolayı öğrencilerin sosyal becerilerinin hedeflendiği şekilde gelişmediği sonucuna ulaşmıştır.

Yurt dışında yapılan araştırmalarda; serbest zaman etkinliklerinin ve ders dışı etkinliklerin öğrencilerin sosyalleşmesine, yaratıcı düşünme becerilerinin gelişmesine, kişilik gelişimlerine, özgüvenlerinin artmasına, okula karşı olumlu tutum geliştirmelerine, akademik başarılarının artmasına, kendilerini daha mutlu hissetmelerine, sorumluluk, iletişim ve grup çalışmaları gibi becerilerin gelişimine katkı sağladığı belirtilmiştir (Fletcher vd., 2003; Gifford \& Dean, 1990; Holloway, 2000). Öğretmenlerin en az katıldıkları görüşler "Serbest etkinlik dersi için yapılan açıklama ve bilgilendirmeler yeterlidir." ve "Serbest 
etkinlik dersinin, öğrencilerin düşünme becerilerini geliştirdiğini düşünüyorum" olmuştur. Öğretmenlerin her ne kadar kendilerini bilgi beceriler konusunda yeterli gördükleri sonucu ortaya çıkmış olsa da en az katılımı bu konuda göstermişlerdir. Özellikle serbest etkinlikler dersi ile ilgili açıklama ve bilgilendirmelere katılımın az olması bu konuda sıkıntılar yaşandığını göstermektedir. Öğretmenlerin bilgi edinme konusunda eksiklik hissetmelerinin nedeni k1lavuz kitap eksikliği ve hizmet içi eğitimlerin yetersizliği olabilir. Gün'ün (2013) çalışmasında da öğretim programının eksikliğinden dolayı öğretmenlerin uygulamalarla ilgili yeterli bilgiye sahip olmadıkları tespit edilmiştir. Bir çok araştırmada öğretmenlerin yeterli bilgi birikimine sahip olmamaları, öğretmenlere yeteri kadar rehberlik edilmemesi, hizmet içi eğitimlerin olmayışı ve kılavuz kitap eksiklikleri gibi nedenlerle uygulama sürecinde ne yapacaklarını bilemedikleri ve etkinlikler anlamında tekrara düştükleri ortaya çıkmıştır (Demir, 2016; Dündar \& Karaca, 2011; Sevim-Yılmaz, 2015). Bu bulguların aksine Sargın (2014) çalışmasında öğretmenlerin yeterli bilgi ve beceriye sahip olduklarını belirtmiştir.

Etkinlikler boyutunda elde edilen bulgulara göre öğretmenlerin serbest etkinlikler dersinde en fazla yer verdikleri etkinliklerin okuma, güzel konuşma ve yazma alışkanlığı kazandırmaya yönelik etkinlikler olduğu belirlenmiştir. Bu etkinliklere çok fazla yer verilmesinin nedeni kolay uygulanabilir olması ve öğrencilerin yazma becerilerinin geliştirmek istenmesi olabilir. Aynı şekilde Yılmaz-Gündüz (2014) serbest etkinlikler dersinde en çok tercih edilen etkinliklerin okuma, güzel konuşma ve yazma etkinliklerinin olduğunu tespit etmiştir. Bozpolat (2016) da araştırmasında serbest etkinlikler dersinde öğretmenlerin sırasıyla anlama ve anlatma etkinlikleri, kitap okuma, bulmaca, eğitici oyunlar, film izleme, şarkı söyleme, resim, drama-tiyatro, el işi çalışmaları, diğer dersleri takviye-ödev, puzzle ve bilgi yarışmaları etkinliklerine yer verdiğini belirtmiştir. Şen ve Sarıkaya'nın (2015b) çalışmasında serbest etkinlikler dersinde öğretmenlerin en fazla tercih ettikleri etkinlikler okuma etkinlikleri, dinleme etkinlikleri ve oyun etkinlikleri olmuştur.

Diğer derslerin takviyesinin yapıldığına dair bulgular "bazen” yani orta düzeyde tespit edilmiştir. Diğer derslerin takviyesinin sergi, gezi-gözlem, halk oyunları, sebze-meyve yetiştirme etkinliklerinden daha çok yapıldığına dair bulgular elde edilmiştir. Sargın (2014), araştırmalarında sınıf öğretmenlerinin serbest etkinlikler dersinde diğer derslerin etkinliklerine kısmen (bazen) yer verdiklerini gösteren bulgulara ulaşmışlardır. Birgül (2018) araştırmasında öğretmenlerin bazen serbest etkinlikler dersini diğer derslerdeki eksikleri 
telafi etmek için kullandıklarını belirtmiştir. Öğretmenler serbest etkinlikler dersinde orta düzeyde yani “bazen” sorunlar yaşandığını belirtmişlerdir. Araştırmanın bulgularına göre öğretmenlerin en fazla sorun yaşadıkları konular sırasıyla yeterli araç-gerecin olmaması, sınıfların kalabalık olması, kılavuz kitapların olmayışı ve okulun fiziki yapısının yetersizliğidir. Alanyazına göre serbest etkinlikler dersi ile ilgili öğretmenlerin yaşadıkları sorunlar; kılavuz kitap eksikliği, fiziki ortam ve alt yapı eksikliği (Birgül, 2018); fiziki ortam ve materyal yetersizlikleri (Bozpolat, 2016); ders içeriğinin esnek olması, ders saatinin fazla olması, okulların fiziki yapısının yetersizliği, ders programının olmaması, sınıf mevcutlarının kalabalık olması ve araç-gereç eksikliği (Özsel, 2016); fiziki koşulların yetersizliği, sınıfların kalabalık olması ve araç gereç yetersizliği (Sevim-Yılmaz, 2015); fiziki şartların yetersizliği ve sınıf mevcutlarının kalabalık olmasıdır (Yılmaz-Gündüz, 2014).

Öğretmenlerin en fazla katılım gösterdikleri öneriler sırasıyla; “etkinlikler öğrenci seviyesine uygun olmalı, etkinlikler için uygun araç-gereç temini sağlanmalı, farklı etkinlikler yapılmalı, özel etkinlik mekânları düzenlenmeli, etkinliklerin niteliğine göre ilgili kurumlarla işbirliği yapılmalı, kılavuz kitap hazırlanmalı ve öğretim programı olmalıdır". Alanyazına göre öğretmenler tarafından sunulan öneriler şu şekildedir: Fiziksel mekân iyileştirilmeli, materyal eksikliği giderilmeli, belli bir öğretim programı olmalı, kılavuz kitap olmalı (Bozpolat, 2016; Kazu \& Aslan, 2013; Sevim-Yılmaz, 2015; Yılmaz-Gündüz, 2014), öğrenci düzeyi dikkate alınmalı (Aydın vd., 2012; Gömleksiz \& Özdaş, 2013), takviye dersleri yapılmamalı, farklı etkinliklere yer verilmeli (Bozpolat, 2016; Sevim-Yılmaz, 2015), hizmet içi eğitimler verilmeli (Aydın vd., 2012; Dündar \& Karaca, 2011; Gün, 2013; Kazu \& Aslan, 2013; Yılmaz-Gündüz, 2014), sınıf mevcutları makul düzeyde olmalı (Sevim-Yılmaz, 2015; YılmazGündüz, 2014), serbest etkinlikler dersi ilgili branş öğretmenleri tarafından okutulmalı (Bozpolat, 2016; Dündar \& Karaca, 2011; Gün, 2013; Sevim-Yılmaz, 2015) veli katılımı sağlanmalıdır (Aydın vd., 2012).

Öğretmenlerin serbest etkinlikler dersine yönelik görüşlerinin cinsiyet değişkenine göre farklılaşmadığı tespit edilmiştir. Benzer şekilde Demir (2016), Şen ve Sarıkaya (2016), Sargın'ın (2014) yaptıkları çalışmalar da bu bulguyu destekler niteliktedir. Bu durumun aksine öğretmenlerin serbest etkinlikler dersi ile ilgili görüşlerinin cinsiyet değişkenine göre farklılaştığını gösteren çalışmalara göre; Özsel (2016) erkek öğretmenlerin etkinlikler boyutunu kadın öğretmenlere göre daha fazla dikkate aldıklarını ve uyguladıklarını, SevimYilmaz (2015) erkek öğretmenlerin öğretim hizmetlerinin niteliğini belirleyen öğelerin 
kullanımında anlamlı düzeyde daha yüksek olduğunu, Aydemir vd. (2015) “Serbest etkinlik ders planlamasını öğrencilerle birlikte yapmaktayım" görüşüne erkek öğretmenlerin daha fazla katılım gösterdiklerini, Gün (2013) serbest etkinlikler dersinde sınıf yönetimi konusunda öğretmenlerin \%46'sının sorun yaşadığını ve kadın öğretmenlerin erkek öğretmenlere göre bu konuda daha çok zorlandığını, Gömleksiz ve Özdaş (2013) serbest etkinlikler ders kazanımlarının gerçekleşme düzeyi ile ilgili kadın öğretmenlerin puanlarının erkek öğretmenlerin puanlarından daha yüksek olduğunu, Özdemir ve Alat (2012) öğretmenlerin serbest etkinlikler dersine yönelik tutumlarının “önem” alt boyutunda erkek öğretmenler tarafından anlamlı farklılıklar olduğunu belirtmiştir.

Öğretmenlerin ilkokullarda uygulanan serbest etkinlik dersine ilişkin görüşleri, mesleki kıdemlerine bağlı olarak anlamlı bir şekilde farklılaşmamaktadır. Ancak, 1-5 yıl arası mesleki kıdem grubundaki öğretmenlerin diğer kıdem gruplarında yer alan öğretmenlere nazaran ilkokullarda uygulanan serbest etkinlikler dersini değerlendirmeye yönelik tüm boyutlardaki katılımlarının daha düşük düzeyde olduğu anlaşılmaktadır. Gömleksiz ve Özdaş (2013), Demir (2016) araştırmalarında da serbest etkinlikler dersi ile ilgili öğretmen görüşlerinin mesleki kıdeme göre farklılaşmadığ ${ }_{1}$ belirlenmiştir. Bu durumun aksine Şen ve Sarıkaya'nın (2015c) çalışmasında öğretmenlerin mesleki kıdemleri arttıkça drama, tiyatro ve sanat etkinlikleri kullanımının azaldığı, satranç ve eksik kalmış kazanımları tamamlama çalışmalarının arttı̆̆ı gözlemlenmiştir. Şen ve Sarıkaya (2016) araştırmalarında öğretmenlerin mesleki kıdemlerinin artmasıyla serbest etkinlikler dersinin amacına hizmet etme derecesine yönelik inançlarının azaldığını belirtmiştir. Özsel'in (2016) araştırmasında öğretmenlerin serbest etkinlikler dersi ile ilgili planlama, etkinlikler ve sorunlar alt boyutlarında mesleki kıdeme göre anlamlı farklılık olduğu belirlenmiştir. Sargın (2014) araştırmasında 1-5 yıllık öğretmenlerin serbest etkinlikler dersini daha fazla gerekli gördüklerini tespit etmiştir. Özdemir ve Alat (2012) çalışmalarında serbest etkinlikler dersine yönelik tutumların 1-10 yıllık mesleki kıdeme sahip öğretmenlerin diğer mesleki kıdeme sahip öğretmenlere göre farklılaştığını tespit etmişlerdir.

Serbest etkinlikler dersine yönelik öğretmen görüşlerinin sınıf mevcutlarına göre sorunlar boyutunda farklılaşma olduğu tespit edilmiştir. Elde edilen sonuçlara göre 35 ve üzeri sınıf mevcuduna sahip olan öğretmenlerin diğer sinıflara göre serbest etkinlikler dersinde daha fazla sorun yaşadıkları tespit edilmiştir. Sınıf mevcudu 5-14 olan öğretmenlerin planlama, uygulama, etkinlikler ve öneriler boyutuna katılımlarının daha 
yüksek olduğu gözlemlenmiştir. Serbest etkinlikler dersinde kalabalık sinıflarda etkinlikleri gerçekleştirme ve sınıfı kontrol etmek güçleştiği için öğretmenlerin sorunlar yaşadığını söylenebilir. Birçok farklı araştırmada sınıf mevcutlarının kalabalık olmasının serbest etkinlikler dersinde önemli bir sorun olarak ortaya çıktığ1 görülmüştür (Bozpolat, 2016; Dündar \& Karaca, 2011; Gün, 2013; Gürbüztürk \& Çakmak, 2017). Kalabalık sınıflarda farklı etkinlikleri gerçekleştirmek, sınıfın tamamını kontrol altında tutmak güçleşmektedir. Bu yüzden öğretim faaliyetleri verimli bir şekilde gerçekleştirilememektedir. Kalabalık sinıflarda öğretmenin öğrencileri motive etmesi ve yönlendirebilmesi en az seviyede olmaktadır (Öztürk, 2006). Sınıf mevcudunun daha az olduğu sınıflarda öğrencilerin akademik başarıları artmaktadır (Yıldırım, 2014). Bu durumun aksine Özsel (2016) çalışmasında 5-14 kişilik sınıflarda görev yapan öğretmenlerin serbest etkinlikler dersinde sorunlar yaşadığını gösteren bulgulara ulaşmıştır. Sınıf mevcudu düşük olan sınıflarda sınıf havasını yakalamak güç olduğundan etkinlikleri gerçekleştirmede sorunlar yaşanabileceğini belirtmiştir. Şen ve Sarıkaya'nın (2016) araştırmalarında ise serbest etkinlikler dersinin amacına hizmet etme derecesine olan inanç ile sınıf mevcudu arasında anlamlı ilişki tespit edilmemiştir.

Öğretmenlerin serbest etkinlikler dersine yönelik görüşlerinin sınıf düzeyi değişkenine göre anlamlı bir farklılık göstermediği tespit edilmiştir. Benzer şekilde Özsel (2016), Gömleksiz ve Özdaş'ın (2013) araştırmasında da serbest etkinlikler dersinin sınıf düzeyi değişkenine göre farklılaşmadığı tespit edilmiştir. Bu durumun aksine SevimYılmaz'ın (2015) çalışmasında öğretmenlerin serbest etkinlikler uygulaması ile ilgili görüşlerinin sınıf düzeyi değişkenine göre farklılaştığı görülmüştür. 1. sınıfı okutan öğretmenlerin diğer sinıfları okutan öğretmenlere göre serbest etkinlikler dersi ile ilgili görüşlerinin anlamlı düzeyde düşük olduğu belirlenmiştir. Gürbüztürk ve Çakmak'ın (2017) çalışmasında da serbest etkinlikler dersinde etkinlik seçimini etkileyen faktörler arasında sınıf düzeyinin belirleyici olduğu tespit edilmiştir. Öğretmenlerin 1. sınıflarda hikaye/masal okuma etkinliği, 2. sınıflarda okuduğunu anlama, bilgi yarışmaları, eğitici oyunlar ve 3. sınıflarda bulmaca, beceri yarışmaları, oyun ve drama etkinliklerini daha çok tercih ettikleri belirlenmiştir.

Öğretmenlerin serbest etkinlik saatlerine ilişkin görüşleri ile mezun olunan fakülte değişkeni arasında anlamlı bir ilişkinin olmadığı tespit edilmiştir. Benzer şekilde Demir (2016), Özsel (2016) ve Sevim-Yılmaz’ın (2015) çalışmasında da öğretmenlerin serbest 
etkinlikler dersine ilişkin görüşlerinin eğitim durumlarına göre farklılaşmadığı tespit edilmiştir. Bu durumun aksine Şen ve Sarıkaya'nın (2016) çalışmasında serbest etkinlikler dersinin amacına hizmet etme derecesine olan inanç ile öğretmenlerin mezun oldukları öğretim programı arasında anlamlı bir ilişki olduğu belirlenmiştir. Sınıf öğretmenliği programından mezun olan öğretmenlerin, serbest etkinlikler dersinin amacına hizmet etme derecesine olan inançlarının daha fazla olduğu tespit edilmiştir. Hatta mezun olunan programlar eğitim alanından uzaklaştıkça dersin amacına hizmet etme derecesine olan inancın azaldı̆̆ı görülmüştür.

Öğretmenlerin, ilkokullarda uygulanan serbest etkinlik saatlerine ilişkin görüşlerinin lisansüstü eğitim alma durumlarına göre planlama ve uygulama boyutlarında lisansüstü eğitim alan öğretmenlerin lehine anlamlı fark olduğu görülmüştür. Lisansüstü eğitimin öğretmenlerin kendilerini geliştirme ve yenileme süreçlerine etkisinin ve katkısının olduğu söylenebilir. Araştırmanın diğer bulgularına göre etkinlikler, sorunlar ve öneriler boyutlarında lisansüstü eğitim alma ve almama durumlarının farklılaşmadığı tespit edilmiştir. Bu durumun aksine Özsel'in (2016) çalışmasında serbest etkinlikler dersinin uygulanmasına yönelik olarak öğretmen görüşlerinin lisansüstü eğitim alma ve almama durumlarına göre farklılaşmadığ

Elde edilen bu sonuçlardan yola çıkarak aşağıdaki önerilere yer verilebilir:

- Serbest etkinlikler dersinde öğretmenler tarafından okuma, güzel konuşma ve yazma etkinliklerine fazla yer verilmesi öğrencileri sıkabileceğinden onların daha fazla eğlenebilecekleri ve farklı becerilerini geliştirebilecekleri etkinliklere yer verilebilir.

- Serbest etkinlikler dersinde diğer derslerin takviyesi yapılmamalı, bunun yerine çeşitli etkinliklere yer verilmesi faydalı olabilir.

- Okullarda serbest etkinlikler dersi uygulamalarının verimli olması açısından gerekli araç-gereçlerin sağlanması dersin işlenişinin etkililiğini arttırabilir.

- Serbest etkinlikler dersinde yapılacak etkinliklerle ilgili çeşitli kurumlarla işbirliği yapılarak dersin etkililiği artırılabilir.

- Okulların fiziki şartlarının iyileştirilmesi serbest etkinlikler dersinin daha verimli işlenebilmesine katkı sağlayabilir.

- Öğretmenlerin lisansüstü eğitim almaları serbest etkinlikler dersi ile ilgili çalışmalarında, alan hakkında ve kendi gelişimleri açısından faydalı olabilir. 
Yapılacak araştırmalara yönelik öneriler:

- Serbest etkinlikler dersinde öğretmenler tarafından yer verilen çalışmalar ve etkinliklerin belirlenmesine yönelik çalışmalar yapılabilir.

- Lisansüstü eğitim alma/almama durumunun öğretmenlerin mesleki gelişimlerini ve serbest etkinlikler dersi ile görüşlerini nasıl etkilediğini belirlemeye yönelik çalışmalar yapılabilir.

- Serbest etkinlikler dersi ile ilgili öğretmenlerin görüşlerini almaya yönelik karma çalışmalar yapılabilir.

\section{Bilgilendirme}

Bu çalışma, ikinci yazarm yüksek lisans tezinden üretilmiş olup Siirt Üniversitesi Rektörlü̆ğ̈̈ Bilimsel Araştırmalar Projeleri Koordinatörlüğ̈̈ (BAP) tarafindan 2018-SïÜSOS-026 nolu proje kapsamında desteklenmiştir.

Bu çalışmada kullanılan verilerin 2020 yılı öncesine ait olduğu araştırmacılar tarafindan onaylanmıştır.

Yazar Katkı Beyanı

Mehtap SARAÇOĞLU: Kavramsallaştırma, metodoloji, danışmanlık ve denetim (ölçme araci, veri analizi), inceleme-yazma ve düzenleme

Yunus Emre ÇIFTÇİ: Kavramsallaştırma, veri toplama, ön taslak yazımı ve düzenleme

\section{Kaynaklar}

Aydemir, H., Bozkurt, E., \& Şekerci, H. (2015). Serbest etkinlik derslerine yönelik sinıf öğretmenlerinin görüşleri. Turkish Journal of Educational Studies, 2(2), 41-74.

Aydın, A., Bakırcı, H., \& Ürey, M. (2012). Serbest etkinlik çalışmaları dersine yönelik sınıf öğretmenlerinin görüşleri. Milli Ĕ̆itim Dergisi, 193, 215-228.

Baysen, E. \& Silman, F. (2012). Yapılandırmacı yaklaşım. In Z. Kaya (Ed.) Öğrenme ve öğretme kuramlar, yaklaşımlar, modeller (ss. 197-226). Ankara: Pegem Akademi Yayıncılık.

Birgül, S. (2018). Serbest etkinlikler dersinin incelenmesi: Nallihan örneği. (Yayımlanmamış Yüksek Lisans Tezi). Hacettepe Üniversitesi, Ankara.

Bozpolat, E. (2016). İlkokullarda uygulanan serbest etkinlikler dersine ilişkin öğretmen görüşleri. Journal of World of Turks, 8(2), 217-239.

Büyüköztürk, Ş., Kılıç-Çakmak, E., Akgün, Ö. E., Karadeniz, Ş., \& Demirel, F. (2012). Bilimsel araştırma yöntemleri. Ankara: Pegem Akademi Yayıncılık.

Demir, M. (2016). İlköğretimde uygulanan serbest etkinlikler dersinin değerlendirilmesi. International Periodical for the Languages, Literature and History of Turkish or Turkic, 11(19), 283-298. 
Dündar, H., \& Karaca, E. T. (2011). İlköğretim okullarında serbest etkinlikler dersinin değerlendirilmesi. Erzincan Eğitim Fakültesi Dergisi, 13(2), 105-121.

Fletcher, A. C., Nickerson, P. \& Wright, K. L. (2003). Structured leisure activities in middle childhood: Links to well-being. Journal of Community Psychology, 31(6), 641-659.

Gifford, V., \& Dean, M. (1990). Differences in extracurricular activity participation, achievement and attitudes towards school between ninth grade students attending junior high school and those attending senior high school. Adolescece, 12(44), 323-335.

Gökalp, M. (2014). Öğretme-öğrenme modelleri, grupla öğrenme modelleri. In B. Oral (Ed.), Öğrenme-öğretme kuram ve yaklaşımları (ss. 325-349). Ankara: Pegem Akademi.

Gömleksiz, M. N., \& Özdaş, F. (2013). Serbest etkinlikler dersinin etkililiğine ilişkin öğretmen görüşleri: Nitel bir çalışma. Fırat Üniversitesi Sosyal Bilimler Dergisi, 23(19), 105-118.

Gutek, G. L. (2014). Eğitime felsefi ve ideolojik yaklaşımlar. (Çeviren:N. Kale). Ankara: Ütopya Yayınevi.

Gün, E. S. (2013). Serbest etkinlik uygulamalarının öğretmen görüşlerine göre değerlendirilmesi. Middle Eastern \& Afrian Journal of Education Research, 3, 21-32.

Gürbüztürk, O., \& Çakmak, G. (2017). İlkokulda serbest etkinlikler dersinde etkinlik seçimini etkileyen faktörlere ilişkin öğretmen görüşleri. The Journal of İternational Lingual, Social and Educational Sciences, 3(2), 177-190.

Holloway, J. H. (2000). Extracurricular activities: The path to academic success. Educational Leadership, 57(4), 211-222.

Ika-Mayasari, L., Akbar, M., \& Sari, E. (2020). The effect of organizational culture and communication in decision making by school principals. International e-Journal of Educational Studies (IEJES), 4 (7), 122-132. DOI: 10.31458/iejes.615719

İlhan-Beyaztaş, D., Kaptı, S. B., \& Senemoğlu, N. (2013). Cumhuriyetten günümüze ilkokul/ilköğretim programlarının incelenmesi. Ankara Üniversitesi Ĕ̆itim Bilimleri Fakültesi Dergisi, 46(2), 319-344.

Karasar, N. (2015). Bilimsel araştırma yöntemi: Kavramlar ilkeler teknikler. Ankara: Nobel Akademik Yayıncılık.

Kazu, H., \& Aslan, S. (2013). Serbest etkinlikler dersinin birleştirilmiş sınıflarda görev yapan öğretmenlerin görüşlerine dayalı olarak değerlendirilmesi. Pamukkale Üniversitesi Ĕ̆itim Fakültesi Dergisi, 34(2), 133-145.

Köse, E. (2004). İlköğretim öğrencilerinin ders dışı etkinliklerini tercih etme nedenleri. Atatürk Üniversitesi Bayburt Ĕ̆itim Fakültesi Dergisi, 2(3), 46-61.

Kutluca, T. (2013). Yapılandırmacı öğrenme-öğretme yaklaşımı. In G. Ekici \& M. Güven (Eds.), Yeni öğrenme-öğretme yaklaşımları ve uygulama örnekleri (ss. 620-653). Ankara: Pegem Akademi.

Milli Eğitim Bakanlığ1 [MEB] (2010). Milli eğitim bakanlığı talim ve terbiye kurulu. ilköğretim okulu haftalık ders çizelgesi konulu karar. Karar tarihi: 20.07.2010, Karar 75. yayımlandığı tebliğler dergisi tarihi ve sayısı: ağustos 2010, 2635.

Milli Eğitim Bakanlığı [MEB] (2012). 12 yıl zorunlu eğitim sorular ve cevaplar: Ankara. Retrieved from http://www.meb.gov.tr/duyurular/duyurular2012/12yilsorucevap lar.pdf

Özdemir, Y., \& Alat, K. (2012, Mayıs). Sınıf öğretmenlerinin serbest etkinlik saatine ilişkin tutumları. 11. Ulusal Sını Öğretmenliği Ĕ̆itimi Sempozyumu, Rize: Rize Üniversitesi. 
Özsel, Z. (2016). Serbest etkinlikler dersinin sınıf öğretmenlerinin görüşlerine dayalı olarak incelenmesi. (Yayımlanmamış Yüksek Lisans Tezi). Fırat Üniversitesi, Elazı̆̆.

Öztürk, B. (2006). Sınıfta istenmeyen davranışların önlenmesi ve giderilmesi. In E. Karip (Ed.), Sınıf yönetimi (ss.150-191). Ankara: Pegem Akademi Yayınc1lık.

Sargın, M. (2014). Illkokul programında yer alan serbest etkinlikler dersinde öğretmenlerin kendilerini yeterli görme düzeyleri.(Yayımlanmamış Yüksek Lisans Tezi). Ahi Evran Üniversitesi, Kırşehir.

Sevim-Y1lmaz, L. (2015). Illkokulda uygulanan serbest etkinlik dersinin öğretmen görüşlerine göre değgerlendirilmesi. (Yayımlanmamış Yüksek Lisans Tezi). Atatürk Üniversitesi, Erzurum.

Şen, S., \& Sarıkaya, İ. (2015a). Serbest zaman etkinlikleri dersi kullanımının çeşitli değişkenler açısından incelenmesi. Uluslararası Ĕ̆itim, Bilim ve Teknoloji Dergisi, 1(1), 1-16.

Şen, S., \& Sarıkaya, İ. (2015b). Serbest zaman etkinlikleri dersinde tercih edilen etkinliklerin kullanılma sıklıklarının incelenmesi. Ĕ̆itim Öğretim Araştırma Dergisi, 4(4), 217-227.

Şen, S., \& Sarıkaya, İ. (2015c). Serbest zaman etkinlikleri dersi uygulamalarının mesleki kıdem değişkenine göre incelenmesi. Elektronik Ĕ̆gitim Bilimleri Dergisi, 4(8), 191-205.

Şen, S., \& Sarıkaya, İ. (2016). Serbest etkinlikler dersinin amacına hizmet etme derecesinin öğretmen görüşlerine göre incelenmesi. Adıyaman Üniversitesi Ĕ̆itim Bilimleri Dergisi, 6(2), 344-359.

Tozlu, N. (2014). Eğitimden felsefeye- 1. Erzurum: Bayburt Üniversitesi Yayınları.

Tüfekçi-Aslım, S. (2014). Yapılandırmacı yaklaşım. In S. Büyükalan Filiz (Ed.), Öğrenme öğretme kuram ve yaklaşımları (ss. 336-351). Ankara: Pegem Akademi Yayıncılık.

Yıldırım, N. (2014). Sınıfın fiziksel düzenini oluşturma. In R. Sarpkaya (Ed.), Sınıf yönetimi (ss. 59-74). Ankara: Anı Yayıncilık.

Yılmaz-Gündüz, D. (2014). İlkokul serbest etkinlikler uygulamasına ilişkin bir durum çalışması. (Yayımlanmamış yüksek lisans tezi). Ankara Üniversitesi, Ankara. 